\title{
Globacrochordiceras gen. nov. (Acrochordiceratidae, late Early Triassic) and its significance for stress-induced evolutionary jumps in ammonoid lineages (cephalopods)
}

\author{
Claude Monnet*, 1 , Hugo Bucher ${ }^{2}$, Arnaud Brayard ${ }^{3}$ and James F. Jenks ${ }^{4}$ \\ ${ }^{1}$ Géosystèmes - UMR 8217 CNRS, Université de Lille 1, UFR Sciences de la Terre (SN5), Avenue Paul Langevin, \\ 59655 Villeneuve d'Ascq cedex, France. E-mail: claude.monnet@univ-lille1.fr \\ 2 Paläontologisches Institut und Museum, Universität Zürich, Karl Schmid Strasse 4, 8006 Zürich, Switzerland \\ ${ }^{3}$ UMR CNRS 6282 Biogéosciences, Université de Bourgogne, 6 Boulevard Gabriel, 21000 Dijon, France \\ ${ }^{4} 1134$ Johnson Ridge Lane, West Jordan, Utah 84084
}

Received 28 September 2012

Accepted 4 March 2013

Published 5 August 2013

\section{Key Words}

Ammonoids
Anisian
Evolution
Nevada
South China
Spathian

\begin{abstract}
Globacrochordiceras transpacificum gen. et sp. nov. is an ammonoid (Ammonoidea, Cephalopoda) with a shell characterized by plicate ribbing (rounded and undulating ribs strengthening on the venter without interruption), increasing involution through ontogeny, overhanging and deep umbilical wall, absence of tuberculation, subtriangular whorl section, globose adult shape with a closed umbilicus followed by an abrupt egressive coiling, and a subammonitic adult suture line. This new taxon occurs in Nevada (USA) and in Guangxi (South China). It has its typical occurrence within the Neopopanoceras haugi Zone of late Spathian age (Early Triassic). The plicate ribbing, suture line and general shell shape are diagnostic of the family Acrochordiceratidae. The large adult size, high degree of involution and subammonitic suture line of Globacrochordiceras markedly contrast with the next younger genus of the family (Paracrochordiceras of early Anisian age, Middle Triassic), which is evolute and displays a ceratitic suture shape. Shell coiling and suture line of Globacrochordiceras are closer to that of the youngest member of the family: Acrochordiceras carolinae (late middle Anisian). The latter is the end-member of a long-term morphological evolutionary trend of the family during the early and middle Anisian. This trend composed of classical increases in adult size (Cope's rule), shell involution and suture indentation, lasted ca. four Myr. The sudden morphological evolutionary jump between Globacrochordiceras and Paracrochordiceras at the Spathian/Anisian (Early/Middle Triassic) boundary may correspond to a generalized morphological reset of long-term trends, a process that differs from classic paedomorphic transformations. A dramatic global sea level change and carbon isotope positive excursion at the Early/Middle Triassic boundary both indicate stressful environmental changes that may have triggered this evolutionary jump.
\end{abstract}

\section{Introduction}

The family Acrochordiceratidae (Ammonoidea, Cephalopoda, Mollusca) was established by Arthaber (1911, p. 179) and represents one of the main components of ammonoid faunas during the Anisian (ca. 248-241 Ma; Middle Triassic). Representatives of this family occur in rocks of upper Spathian to middle Anisian (Early-
Middle Triassic) from North America, Arctic, Western Pacific, Tethys and Germanic Basin. The broad palaeogeographical and temporal distribution of this family, as well as its moderate evolutionary rates, suggests that this clade was well-adapted to its environment (Fig. 1).

Based on exceptionally large collections from North America, Monnet et al. (2012) highlighted that the family evolved by displaying significant long-term mor-

\footnotetext{
* Corresponding author
} 
phological evolutionary trends during the Anisian (see discussion). Here we report on the oldest acrochordiceratids recently discovered from the Spathian of Nevada (USA) and of Guangxi (South China). This oldest member of the family represents a new genus and a new species. Although easily distinguishable and clearly belonging to the Acrochordiceratidae (see systematic palaeontology), the new genus displays a morphology which stands in sharp contrast with the temporally succeeding taxa of the family. This new genus brings additional data to the evolutionary history of the group and provides insights on the morphological reactions of ammonoids under intense external stress. We therefore first report on the taxonomy and biostratigraphy of this new acrochordiceratid genus, then provide a short revision of the family, and finally discuss the evolutionary implications of this new ammonoid genus.

\section{Material and geological setting}

The new taxon is based on specimens collected in two distinct regions (Fig. 1): Guangxi (South China) and Nevada (USA). These specimens are part of systematic bed-by-bed collections of Spathian ammonoids (sampled by HB). In Nevada, the new taxon described herein occurs in the upper part of the carbonate unit of the Lower Member of the Prida Formation exposed in Coyote Canyon (northern Humboldt Range). Bucher (1989) described in detail the stratigraphy and facies changes of the Spathian/Anisian boundary in the Humboldt Range.

In South China, most of the material comes from NW Guangxi Province. This area provides numerous exposures covering the interval from the uppermost Permian to the Middle Triassic. The new acrochordiceratid genus occurs in the uppermost part of the Luolou Formation in the Jinya area, which has been described exhaustively by Galfetti et al. (2008). The Luolou Fm. crops out extensively in the Nanpanjiang Basin of the South China Block (see Lehrmann et al. 1998, 2005 and Galfetti et al. 2008), which was located at an equatorial position during the Early Triassic (Gilder et al. 1995). At its type locality, the Luolou Formation is composed of mixed carbonate-siliciclastic rocks deposited in an outer platform setting (for details about lithologies, microfossils and carbon isotope changes, see Galfetti et al. 2007a, 2007b, 2008). The lithological unit of the Luolou Formation yielding the new acrochordiceratid (Unit V in Galfetti et al. 2008) is ca. $40 \mathrm{~m}$ thick and composed of thin-bedded, grey, nodular and highly bioturbated limestones. This unit brackets a conspicuous greywacke horizon (called "Green Bean Rock") of regional extension within its upper part (Galfetti et al. 2008) with a radiometric age of $248.12 \mathrm{Ma}$ (Ovtcharova et al. 2006).

\section{Biostratigraphy}

The standard biochronological scheme of Spathian and Anisian in North America was produced by Silberling \& Tozer (1968), Silberling \& Wallace (1969), Bucher (1989), Tozer (1994b), and Monnet \& Bucher (2005a). Monnet \& Bucher (2005b) analysed the biochronology and biodiversity of Anisian ammonoid faunas from Nevada and British Columbia. The complete taxonomical and biostratigraphical revision of Spathian ammonoids in the USA is in progress (Guex et al. 2005a, 2005b, 2010; Bucher et al., ongoing work). The new taxon sampled in the northern Humboldt Range is associated with Ceccaisculitoides elegans, Subhungarites yatesi, Inyoceras sp. nov., Metadagnoceras pulchrum, Sulioticeras sp. nov., Arnautoceltites sp. nov., and Svalbardiceras aff. S. spitzbergensis. This association of taxa occurs just below an assemblage composed of

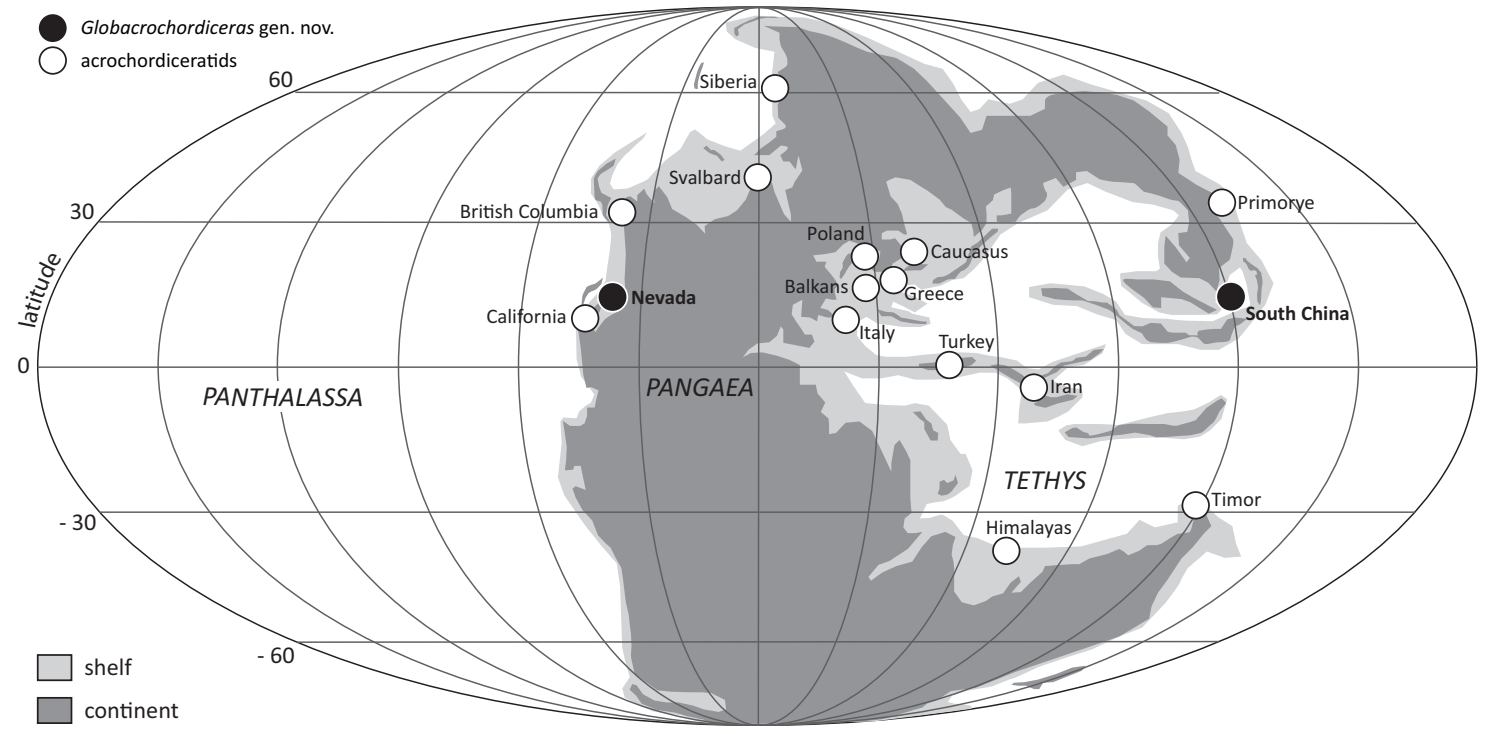

Figure 1. Distribution of Spathian and Anisian ammonoid Acrochordiceratidae (white circles) and the two basins currently recording Globacrochordiceras (black circles). Palaeogeographical reconstruction modified after Blakey (2011). 


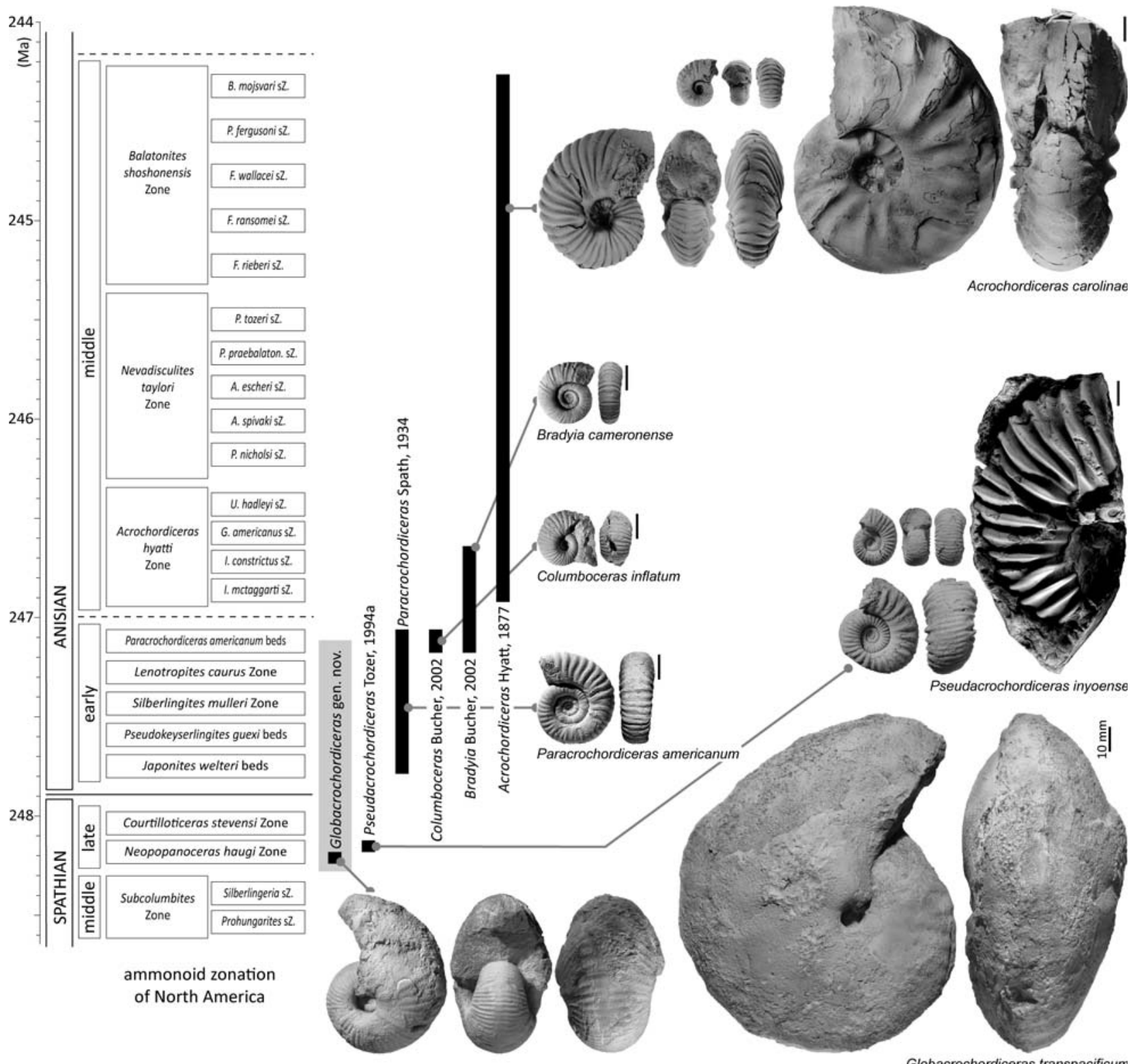

Figure 2. North American ammonoid zonation, stratigraphical age of the newly described genus Globacrochordiceras, and illustration of all genera belonging to the Acrochordiceratidae as revised here. Ammonoid zonation of the Anisian after Monnet \& Bucher (2005a, 2005b) and Monnet et al. (2008). Ammonoid zonation of the Spathian modified after Guex et al. (2010) and Bucher et al. (ongoing work). Age calibration of the ammonoid zonation after Galfetti et al. (2007b). Ammonoid figures (all at the same scale) after Bucher (2002; Bradyia cameronense, pl. 1, figs 9-10; Columboceras inflatum, pl. 1, figs 5-6; Paracrochordiceras americanum, pl. 1, figs 1-2), Guex et al. (2010; the largest figured specimen of Pseudacrochordiceras inyoense, pl. 24, fig. 2), Monnet et al. (2010; Acrochordiceras carolinae, pl. 7, figs 9-11, pl. 10, figs 4-6, and text-fig. 12a-b) and this study (Globacrochordiceras transpacificum gen. et sp. nov.; Pseudacrochordiceras inoyense after unpublished collection of Jim Jenks).

Hemilecanites fastigatus, Neopopanoceras haugi, Keyserlingites pacificus, Prohungarites lenticularis, Pseudacrochordiceras inyoense, and Eodanubites cf. E. costulatus. These two ammonoid faunas are diagnostic of the Neopopanoceras haugi Zone of the late Spathian (Fig. 2).

Preliminary data suggest that the Chinese Spathian biostratigraphical record is rather good and correlates well with the reference succession from North America (Galfetti et al. 2007b). The new genus sampled in NW Guangxi is typically associated with Procarnites, Japonites, Eodanubites zyunensis, Deweveria, Pseudosage- ceras, Paleophyllites, and Ceccaisculitoides. This association of taxa is also diagnostic of the Neopopanoceras haugi Zone in the late Spathian (see references above; Fig. 2). Noteworthy, in Jinya, samples containing the new taxon bracket an ash layer dated of $248.12 \mathrm{Ma} \pm 0.28$ (Ovtcharova et al. 2006; Galfetti et al. 2007b).

The new acrochordiceratid genus is spatially restricted to the low palaeolatitudes, and temporally to the Neopopanoceras haugi Zone (late Spathian, Early Triassic). This zone is documented in the Union Wash Formation in California (Smith 1914; Guex et al. 2010) 
and the Prida Formation in Nevada (Silberling \& Wallace 1969; Bucher 1989; this work), as well as in the Luolou Formation in China (Galfetti et al. 2007a; this work). Several authors (Silberling \& Tozer 1968; Bucher 1989; Tozer 1994a) considered that the haugi Zone correlates with the high-palaeolatitudinal Keyserlingites subrobustus Zone. Although this point of view has been questioned (Waterhouse 1999), the ammonoid faunas recently documented by Guex et al. (2010) corroborate this hypothesis again. The assignment of both zones to either latest Spathian (Early Triassic) or earliest Anisian (Middle Anisian) has also been repeatedly debated (Silberling \& Wallace 1969; Weitschat \& Dagys 1989; Tozer 1994a; Waterhouse 2002). Given the newly described faunas from the United States (Guex et al. 2010; Bucher, ongoing work), the haugi Zone displays clear Spathian affinities with only very few taxa ranging up into the Anisian. Hence, the haugi Zone will be considered of Spathian age throughout the rest of this study.

\section{Systematic palaeontology}

Taxonomical descriptions follow the terminology of Arkell et al. (1957) and Korn (2010). Definition of size classes follows the classification of Korn (2010). The supra-familial classification of Acrochordiceratidae follows Tozer $(1981,1994 b)$ but the infra-familial classification is here revised. The new material described herein is housed at the Palaeontological Institute and Museum of Zürich (PIMUZ; University of Zürich, Switzerland).

Phylum Mollusca Linnaeus, 1758

Class Cephalopoda Cuvier, 1797

Subclass Ammonoidea Zittel, 1884

Order Ceratitida Hyatt, 1884

Superfamily Ceratitaceae Mojsisovics, 1879

Family Acrochordiceratidae Arthaber, 1911, p. 179

\section{Type genus Acrochordiceras Hyatt, 1877}

Diagnosis. Ammonoids characterized by plicate ribbing (rounded ribs enlarging when crossing the venter without interruption), usually high oval to inflated whorl section, and a relatively indented ceratitic to subammonitic suture line without well-individualized auxiliary lobes.

Composition of the family. Only the following genera are here considered as valid members of the family (Fig. 2): Acrochordiceras Hyatt, 1877; Bradyia Bucher, 2002; Columboceras Bucher, 2002; Paracrochordiceras Spath, 1934; Pseudacrochordiceras Tozer, 1994a; and Globacrochordiceras gen. nov. Additional acrochordiceratid genera have been described but are here considered as synonyms to the previously listed genera (see below and Spath 1934, p. 392).

Occurrence. The family shows a broad palaeogeographical distribution (Fig. 1) and occurs in North Ameri- ca (Nevada, California and British Columbia), the Western Pacific (Primorye), the Tethys (Italy, Austria, Hungary, Balkans, Greece, Caucasus, Turkey, Iran, Himalayas and Timor, South China), the Germanic Basin (Poland) and the Arctic (Svalbard, Siberia). It is recorded with certainty from the late Spathian Neopopanoceras haugi Zone (Early Triassic) to the middle Anisian Balatonites shoshonensis Zone (Middle Triassic) (Fig. 2).

Description. Coiling very evolute (serpenticone) to very involute; generally decreasing on outer whorls. Whorl section depressed to moderately compressed, high oval or subtriangular to subquadrangular. Ornamentation composed of thin to strong ribs, which strengthen and are more prominent as they cross the arched venter without interruption; this plicate ribbing is the major diagnostic feature of the family. In addition to the typical ribbing, some species may bear umbilical or lateral tubercles from which may stem usually two or three ribs. Ornamentation on the mature body chamber is commonly, if not invariably, different; ribbing may either completely fade or may strengthen and become more distant but without crossing the venter. Body chamber of about three quarters of a whorl. Suture line ceratitic with smooth saddles to subammonitic with slightly but distinctly crenulated saddles; lobes slightly to deeply indented; formula characteristically 6-lobed (E, L, U2, U3, U1, I).

Remarks. The origin of the family remains poorly understood. Spath (1934, p. 392) briefly discussed the phylogenetic relationship of Acrochordiceratidae and considered three possible origins (Sibiritidae, Danubitidae, and Ceratitidae). Waterhouse (1999, p. 71) argued for a completely different origin and considered Eoptychitidae as a likely source for Acrochordiceratidae. Bucher (2002, p. 282) suggested that Acrochordiceratidae may have branched off from Balatonitidae during the Spathian, because of the common presence of constrictions and plicate ribbing between members of these two families. Now, given the additional documentation available for Acrochordiceratidae, we hypothesize that the family may root into mid-Spathian Columbitidae. However, the origin of Acrochordiceratidae remains unclear and awaits evidence from a detailed phylogenetic analysis of Triassic ammonoids.

\section{Genus Pseudacrochordiceras Tozer}

Figure 2

\footnotetext{
* 1994a Pseudacrochordiceras Tozer, p. 163 (type Acrochordiceras inyoense Smith, 1914, p. 40).
}

Type species. Acrochordiceras inyoense Smith, 1914, p. 40, pl. 34, figs 11-13 from the Union Wash Formation (California).

Diagnosis. Large-sized acrochordiceratid characterized by depressed whorl section (cadicone), rounded flanks, low-arched venter, moderately evolute coiling, strong, slightly concave and rectiradiate ribs, sharp plicate ribbing, and absence of real tubercles, but sometimes presence of faint nodes where ribs branch off (see e.g., Guex et al. 
2010, pl. 23, figs 3-5). Suture line ceratitic with rounded, smooth saddles, moderately crenulated lobes, a narrow external lobe (E) and a small suspensive lobe. Mature shell imperfectly known, with rounded to high-oval whorl section, slightly egressive coiling and with an estimated maximum diameter of ca. $120 \mathrm{~mm}$.

Composition of the genus. Type species only.

Occurrence. The genus is restricted to the late Spathian (Early Triassic). It was originally described from the Neopopanoceras haugi Zone in California (USA) and is now also documented in Nevada.

\section{Genus Paracrochordiceras Spath}

Figure 2

* 1934 Paracrochordiceras Spath, p. 400 (type Acrochordiceras anodosum Welter, 1915, p. 111).

? 1978 Preflorianitoides Wang, p. 158 (type P. reniformis Wang, 1978, p. 158).

1978 Eoacrochordiceras Wang, p. 165 (type E. ziyunense Wang, 1978, p. 165)

1983 Proacrochordiceras Korschinskaya, p. 109 (type P. kiparisovae Korschinskaya, 1983, p. 110)

? 1995 Caucasochordiceras Shevyrev, p. 76 (type Acrochordiceras (Paracrochordiceras) simplex Shevyrev, 1968, p. 128).

Type species. Acrochordiceras anodosum Welter, 1915, p. 111, pl. 89, figs $3 \mathrm{a}-\mathrm{c}$ from Nifoekoko (Timor).

Diagnosis. Small-sized acrochordiceratid distinguished by high-oval to rounded whorl section, serpenticone to very evolute coiling, dense, straight to polyfurcate, rectiradiate, sharp to weak ribs, sharp to subdued plicate ribbing, absence of real tuberculation but presence of parabolic nodes on inner whorls, and ceratitic suture line with narrow external lobe (E) and no suspensive lobe. Maturity is marked by more subquadrangular whorl section and decreasing number of branching ribs, and is reached at shell diameter of ca. $60 \mathrm{~mm}$.

Composition of the genus. Several species of Paracrochordiceras are currently known. This genus is the one having the highest number of species in Acrochordiceratidae. However, several of these species are poorly documented and it is probable that a taxonomical revision accounting for their intraspecific variation will suggest that some of them are conspecific. For instance, some species are distinguished only by a stronger or weaker ribbing (see e.g., discussion of Tozer 1994a on Paracrochordiceras welteri), which typically fits in the common intraspecific variation of coiled ammonoids, which has been coined as the Buckman's first law of covariation (Westermann 1966); see e.g., Kennedy \& Cobban (1976); Silberling \& Nichols (1982); Dagys \& Weitschat (1993); Yacobucci (2004); Hammer \& Bucher (2005); Monnet \& Bucher (2005a); Monnet et al. (2010); and see De Baets et al. (2013) for a comparison with uncoiled ammonoids.

The following species of Paracrochordiceras have been described (published indeterminate species of Paracrochordiceras are omitted here): Sibirites pandya Diener, 1895 (p. 104, pl. 29, fig. 3); Acrochordiceras anodosum Welter, 1915 (p. 111, pl. 89, figs 3a-c); Acrochordiceras (Paracrochordiceras) americanum McLearn, 1946 (p. 16, pl. 5, fig. 1); Acrochordiceras
(Paracrochordiceras) simplex Shevyrev, 1968 (p. 128, pl. 7, fig. 5, text-fig. 32); Eoacrochordiceras ziyunense Wang, 1978 (p. 165, pl. 2, figs 22-26, text-figs 7a-b); Eoacrochordiceras evolutum Wang, 1978 (p. 166, pl. 2, figs 20-21, text-fig. 7c); Paracrochordiceras assereto Fantini Sestini, 1981 (p. 48, pl. 4, fig. 1); Paracrochordiceras denseplicatum Fantini Sestini, 1981 (p. 49, pl. 4, figs 2-3); ? Acrochordiceras (Paracrochordiceras) pacificum Zharnikova, 1981 (p. 34, pl. 4, fig. 5, text-figs 3-4); Proacrochordiceras kiparisovae Korschinskaya, 1983 (p. 110, figs 1a-h, 2a-b); Proacrochordiceras negriense Korschinskaya, 1983 (p. 111, figs 2c, 3); Paracrochordiceras silberlingi Bucher, 1989 (p. 971, pl. 1, figs 6-7, text-fig. 12); Paracrochordiceras mclearni Bucher, 1989 (p. 973, pl. 7, figs 6-7, text-fig. 14); Paracrochordiceras plicatus Bucher, 1989 (p. 974); Paracrochordiceras welteri Tozer, 1994a (p. 164, pl. 1, figs $1 \mathrm{a}-\mathrm{d})$; and Paracrochordiceras benderi Tozer, 1994b (p. 110, pl. 45, figs 2-3, text-fig. 32d).

Occurrence. Species of Paracrochordiceras have been documented worldwide and are restricted to the entire early Anisian (Middle Triassic; Fig. 2) in North America (British Columbia, Nevada), Tethys (Greece, Himalayas, Timor) and Western Pacific (Primorye).

Remarks. When assigning a standard intraspecific variation to species of Paracrochordiceras (see above), several other genera fit within the morphological spectrum of Paracrochordiceras and are considered here as synonyms.

The genus Eoacrochordiceras Wang, 1978 was defined as being closely related to Paracrochordiceras, except for subdued plicate ribbing on the venter and more denticulate lobes. However, this kind of morphology is typical of juvenile Paracrochordiceras (e.g., $P$. americanum; see McLearn 1969, pl. 1, fig. 1; Bucher 1989, pl. 7, figs 3-5; Bucher 2002, pl. 1, figs 1-4) and does not justify assignment to a distinct genus (Waterhouse 1999; this work).

The genus Proacrochordiceras Korschinskaya, 1983 was diagnosed by the presence of umbilical tubercles on inner whorls. However, in our opinion, these supposed tubercles are just faint nodes due to strengthening of ribs when bifurcating. There is no other character to justify a distinction of Proacrochordiceras from Paracrochordiceras Spath, 1934, to which it was not compared when Korschinskaya erected the genus. Although Korschinskaya dated Proacrochordiceras of the subrobustus Zone (late Spathian), it appears that the genus is known only from loose concretions with no other age-diagnostic ammonoid species (see Weitschat \& Dagys 1989). Therefore, we here tentatively consider Proacrochordiceras as a junior synonym of Paracrochordiceras and strongly suspect that the specimens described by Korschinskaya are of early Anisian and not of late Spathian age. Additional data from the type locality of Proacrochordiceras will be necessary to further test this hypothesis.

Preflorianitoides Wang, 1978 can be regarded as related to Paracrochordiceras with its subdued plicate 
ribbing and evolute coiling (Waterhouse 1999), but the low-whorled section and narrow first lateral saddle are also suggestive of a danubitid affinity. Shevyrev (1995) erected the genus Caucasochordiceras since it differs from Paracrochordiceras by a more denticulate suture line and slower increasing whorl height. However, this kind of morphology is also suggestive of danubitids. Besides, Shevyrev (1968) initially placed the simplex species within Paracrochordiceras to which it closely resembles with the evolute coiling, subdued plicate ribbing and absence of tubercles. Hence, the systematic position of Preflorianitoides and Caucasochordiceras remain uncertain and awaits additional material before a firm systematic assignment can be proposed. Noteworthy, taking (or not) into account these genera has no influence on the morphological patterns described after on the evolution of Acrochordiceratidae.

\section{Genus Columboceras Bucher}

Figure 2

* 2002 Columboceras Bucher, p. 281 (type C. inflatum Bucher, 2002, p. 282).

Type species. Columboceras inflatum Bucher, 2002, p. 282, pl. 1, figs 5-6 from the Toad Formation (British Columbia).

Diagnosis. Small-sized acrochordiceratid characterized by depressed, somewhat inflated whorl section, moderately involute coiling, fine, straight and prorsiradiate ribs, sharp plicate ribbing, and absence of tuberculation or faint nodes where ribs branch off. Suture line and adult shell not known (maximum known shell diameter of $21 \mathrm{~mm}$ ).

Composition of the genus. Type species only.

Occurrence. The genus is only known from the Paracrochordiceras americanum Zone (early Anisian, Middle Triassic) in the Toad Formation of British Columbia.

\section{Genus Bradyia Bucher}

Figure 2

* 2002 Bradyia Bucher, p. 282 (type B. cameronense Bucher, 2002,
p. 282).

Type species. Bradyia cameronense Bucher, 2002, p. 282, pl. 1, fig. 35, text-fig. 4 from the Toad Formation (British Columbia).

Diagnosis. Small to medium-sized acrochordiceratid distinguished by rounded whorl section, moderately evolute coiling, fine, straight and prorsiradiate ribs, subdued plicate ribbing, presence of constrictions, absence of tuberculation, and a subammonitic suture line with deeply indented and broad lateral lobe. The presence of constrictions makes this genus very distinct among Acrochordiceratidae. Adult shell morphology not known (maximum known shell diameter of ca. $60 \mathrm{~mm}$ ).

Composition of the genus. Two species belong to this genus: Bradyia cameronense Bucher, 2002 (p. 282, pl. 1, fig. 35, text-fig. 4); and Acrochordiceras coyotense Bucher, 1992 (p. 152, pl. 6, figs 17-21).

Occurrence. The genus is known in the Paracrochordiceras americanum Zone (early Anisian, Middle Triassic) from the Toad Formation of British Columbia and in the Acrochordiceras hyatti Zone (middle Anisian, Middle Triassic) from the Prida Formation of northwest Nevada (Humboldt Range).

\section{Genus Acrochordiceras Hyatt}

Figure 2

* 1877 Acrochordiceras Hyatt, p. 124 (type A. hyatti Meek, 1877, p. 124).

1907 Haydenites Diener, p. 72 (type H. hatschekii Diener, 1907, p. 72).

1916 Silesiacrochordiceras Diener, p. 101 (type Ammonites (Acrochordiceras) damesii Noetling, 1880, p. 334).

1934 Epacrochordiceras Spath, p. 401 (type Acrochordiceras portisi Martelli, 1906, p. 132).

Type species. Acrochordiceras hyatti Meek, 1877, p. 124, pl. 11, fig. 5a [only].

Diagnosis. Large-sized acrochordiceratid characterized by compressed to depressed shell, moderately evolute to involute coiling, rounded and low-arched venter, abrupt umbilical shoulders, slightly sinuous to straight, rectiradiate ribs, plicate ribbing, a single row of tubercles from which may arise several ribs, presence of parabolic nodes on inner whorls, and ceratitic to subammonitic suture line with smoothly crenulated saddles and deeply indented lobes. Mature body chamber with a smooth venter, simple ribs bearing marginal swellings, and subquadrangular whorl section. Adult shell diameter up to ca. $250 \mathrm{~mm}$.

Composition of the genus. Monnet et al. (2010) thoroughly revised the genus and considered that Acrochordiceras contains only four valid species: Ammonites (Acrochordiceras) damesii Noetling, 1880 (p. 334); Acrochordiceras carolinae Mojsisovics, 1882 (p. 141); Acrochordiceras hyatti Meek, 1877 (p. 124); and Haydenites hatschekii Diener, 1907 (p. 72).

Occurrence. The genus Acrochordiceras ranges throughout the entire middle Anisian (Middle Triassic; Fig. 2). It occurs mainly in North America (Nevada) and the Tethys (Alps, Bosnia, Turkey, Himalayas, South China).

\section{Genus Globacrochordiceras nov.}

Figure 2

Type species. Globacrochordiceras transpacificum gen. et sp. nov. Diagnosis. As for the type species.

Derivation of name. Genus name refers to the globular whorl shape with an almost closed umbilicus and group affinity of the fossil.

Composition of the genus. Type species only.

Occurrence. As for the type species.

Description. As for the type species.

Remarks. The genus Globacrochordiceras is a typical acrochordiceratid with its plicate ribbing, its roughly rounded high-oval whorl section, and its subammonitic suture line. From a general point of view, Globacrochordiceras differs from all other acrochordiceratids by its very involute coiling and its overhanging umbilical wall. 
Another acrochordiceratid genus occurred in the late Spathian (Early Triassic): Pseudacrochordiceras Tozer, 1994a. Three genera of Acrochordiceratidae (Fig. 2) existed during the early Anisian (Middle Triassic): Paracrochordiceras Spath, 1934; Columboceras Bucher, 2002; and Bradyia Bucher, 2002. Finally, a last additional genus occurred in the middle Anisian: Acrochordiceras Hyatt, 1877.

Pseudacrochordiceras is a large-sized, depressed, moderately evolute, strongly ribbed shell with a ceratitic suture line. Globacrochordiceras is thus morphologically very close to Pseudacrochordiceras and differs by having more involute coiling, overhanging umbilical wall, weaker ribs, and more complex suture line with deeply indented lobes.

Paracrochordiceras is a small-sized, evolute, subquadrate and depressed shell with sharp to subdued plicate ribbing, absence of tuberculation (except discrete lateral parabolic nodes on innermost whorls), and ceratitic suture line. Therefore, Globacrochordiceras differs from Paracrochordiceras by having very involute coiling, subtriangular whorl section, overhanging umbilical wall, and larger adult shell diameter.

Columboceras is a small-sized, depressed, subcircular, moderately evolute, finely ribbed shell without tuberculation. Although morphologically relatively close, Globacrochordiceras differs from Columboceras by having subtriangular whorl section, overhanging umbilical wall, thinner ribs, and significantly larger adult shell diameter.

Bradyia is a small-sized, non-tuberculated, evolute, subcircular shell with a subammonitic suture line and characterized by constrictions. Hence, Globacrochordi- ceras differs from Bradyia by subtriangular whorl section, involute coiling, overhanging umbilical wall, larger adult shell diameter, and absence of constrictions.

Acrochordiceras covers a large morphological spectrum because of its long-term evolutionary trends during the middle Anisian (see Monnet et al. 2010, 2012). It is a medium- to large-sized shell with moderately evolute to involute coiling, rather subquadrate, compressed to depressed whorl section, ceratitic to subammonitic suture line, and the presence of one row of tubercles. Therefore, Globacrochordiceras differs from Acrochordiceras by subtriangular whorl section, more involute coiling, overhanging umbilical wall, and absence of tuberculation.

\section{Globacrochordiceras transpacificum gen. et sp. nov.}

Figures 3-9

Holotype. PIMUZ 29402 (Figs 4B, 7C-E), Loc. JIN 78, Jinya (Guangxi, South China); Neopopanoceras haugi Zone (late Spathian, Early Triassic).

Diagnosis. Acrochordiceratid showing the typical plicate ribbing (rounded ribs enlarging when crossing the venter without interruption) and characterized by very involute coiling (increasing through ontogeny), overhanging and deep umbilical wall, absence of tuberculation, and globular to subtriangular whorl section. Mature body chamber with subdued ribbing. Adult suture line subammonitic with deeply indented lobes. Adult shell diameter up to ca. $150 \mathrm{~mm}$.

Derivation of name. Species name refers to the occurrence of the species on both West and East sides of Panthalassa.

Material. Nineteen measured specimens from Jinya (Guangxi, South China) (samples: JIN 71 and JIN 78) and from the northern Humboldt

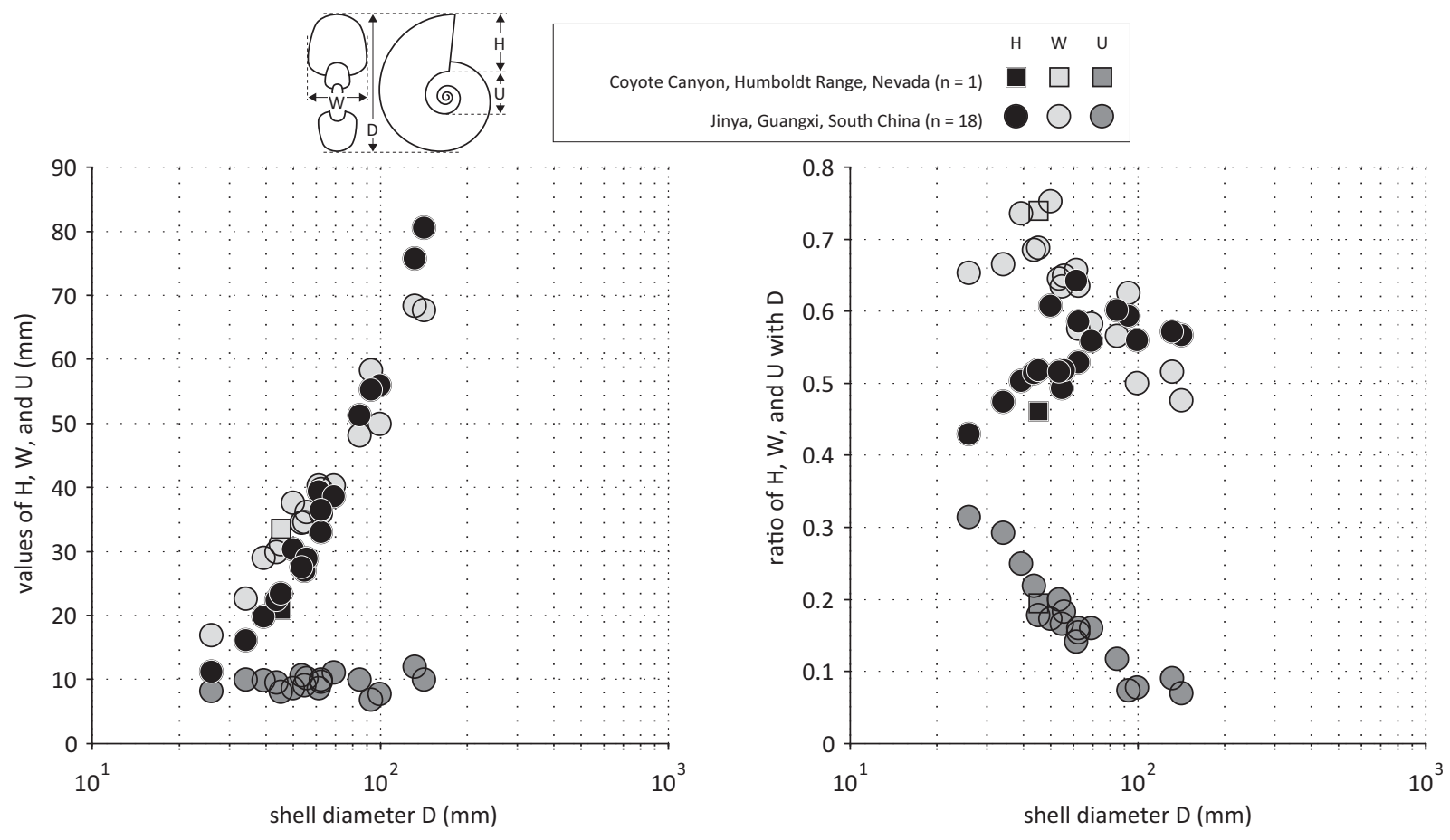

Figure 3. Measurements of the classical geometrical parameters of the ammonoid shell for Globacrochordiceras transpacificum gen. et sp. nov. from Guangxi (South China) and Nevada (USA). D, shell diameter; H, whorl height; U, umbilical diameter; W, whorl width. 


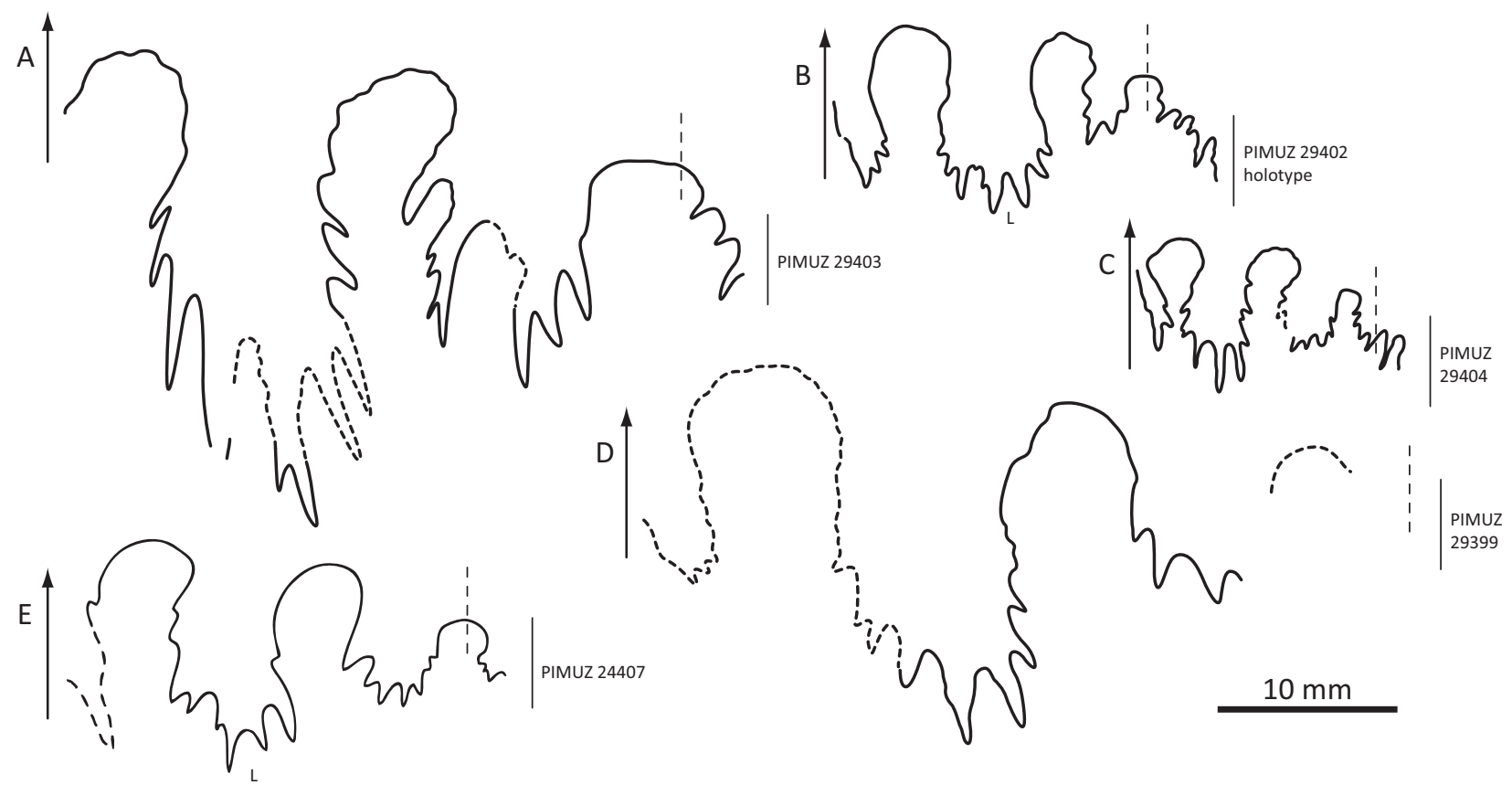

Figure 4. Suture lines of Globacrochordiceras transpacificum gen. et sp. nov. from the Neopopanoceras haugi Zone (upper Spathian, Early Triassic); × 2. A. PIMUZ 29403, loc. JIN 71, Jinya (Guangxi, South China); B. PIMUZ 29402, loc. JIN 78, Jinya (Guangxi, South China), holotype; C. PIMUZ 29404 (suture reversed), loc. JIN 71, Jinya (Guangxi, South China); D. PIMUZ 29399, loc. JIN 78, Jinya (Guangxi, South China); E. PIMUZ 24407 (suture reversed), loc. HB 110, northern Humboldt Range (Nevada, USA).

Range (Nevada, USA) (sample: HB 110). The four classical geometrical parameters of the ammonoid shell (shell diameter D, whorl height $\mathrm{H}$, whorl width $\mathrm{W}$, and umbilical diameter $\mathrm{U}$ ) describe the quantitative morphological range of the species (Fig. 3)

Occurrence. The species occurs in the Neopopanoceras haugi Zone (late Spathian, Early Triassic) from the
NW Guangxi (South China) and from the northern Humboldt Range (Nevada, USA). The species, although scarcely known, shows a distribution restricted to low latitudes. Note that although the genera Globacrochordiceras and Pseudacrochordiceras both occur in the haugi Zone, they did not actually co-exist in time and
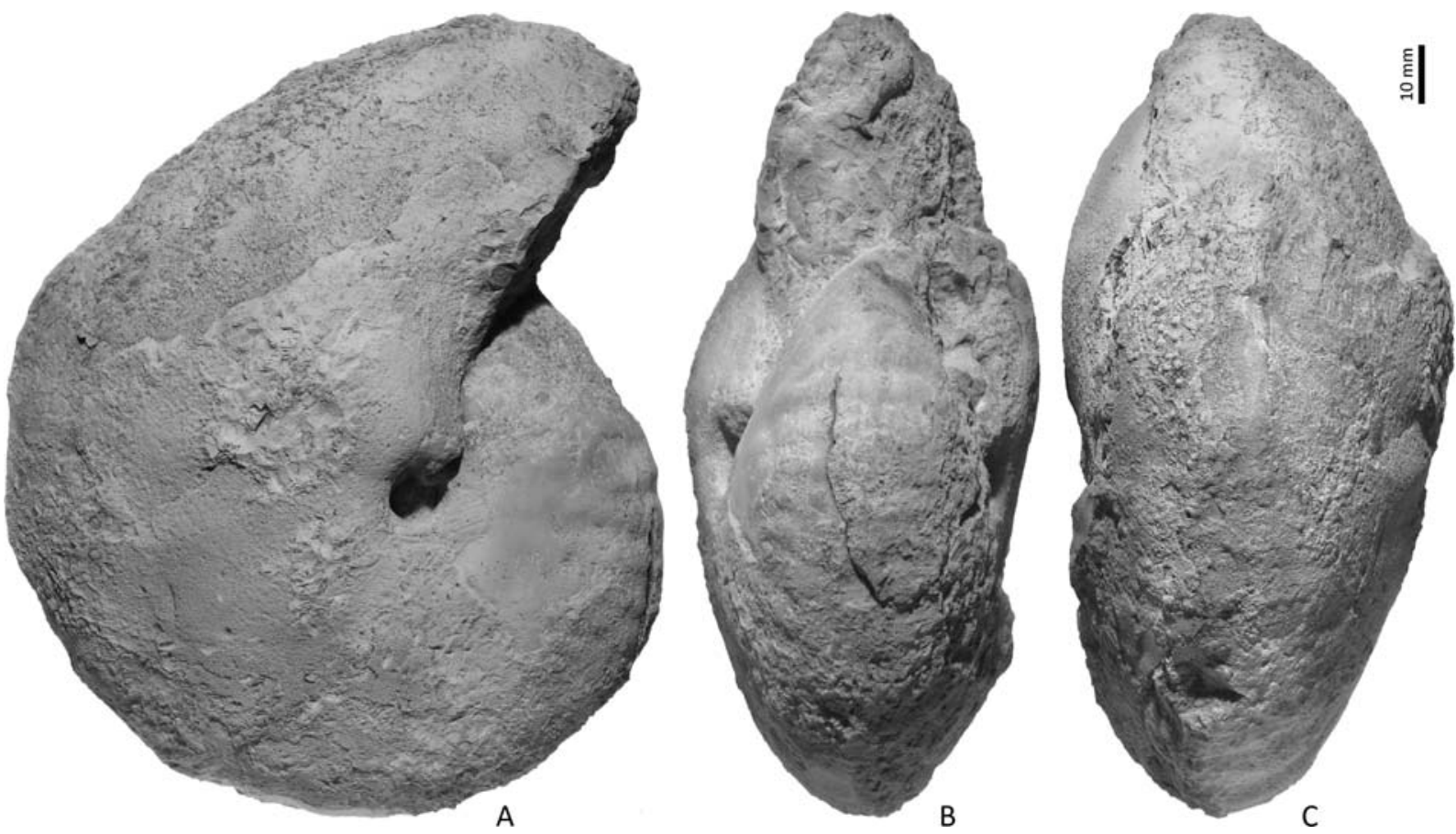

Figure 5. Globacrochordiceras transpacificum gen. et sp. nov. A-C. PIMUZ 29399, sample JIN 78, Jinya, Guangxi (South China); Neopopanoceras haugi Zone (upper Spathian, Early Triassic); mature specimen. 

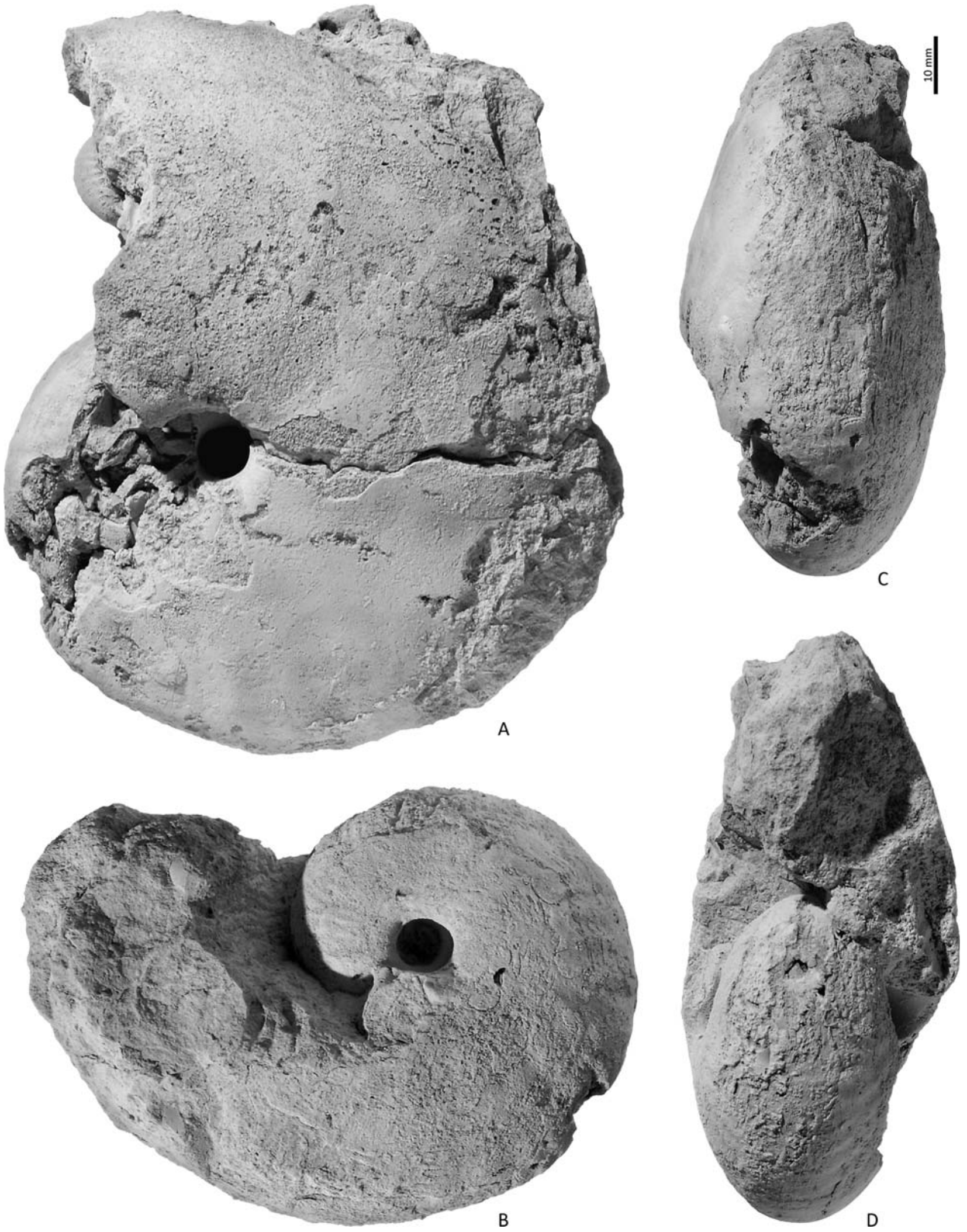

Figure 6. Globacrochordiceras transpacificum gen. et sp. nov. A-D. PIMUZ 29400, sample JIN 71, Jinya, Guangxi (South China); Neopopanoceras haugi Zone (upper Spathian, Early Triassic); submature specimen; $\times 1$.

space. In the northern Humboldt Range, which is the single area where the two genera are both present, Globacrochordiceras occurs in strata slightly older, and thus represents the oldest described member of the family.
Noteworthy, Globacrochordiceras transpacificum displays a peculiar distribution in space and time. The species is restricted to the low-palaeolatitude intertropical belt in both east and west sides of the wide ocean 

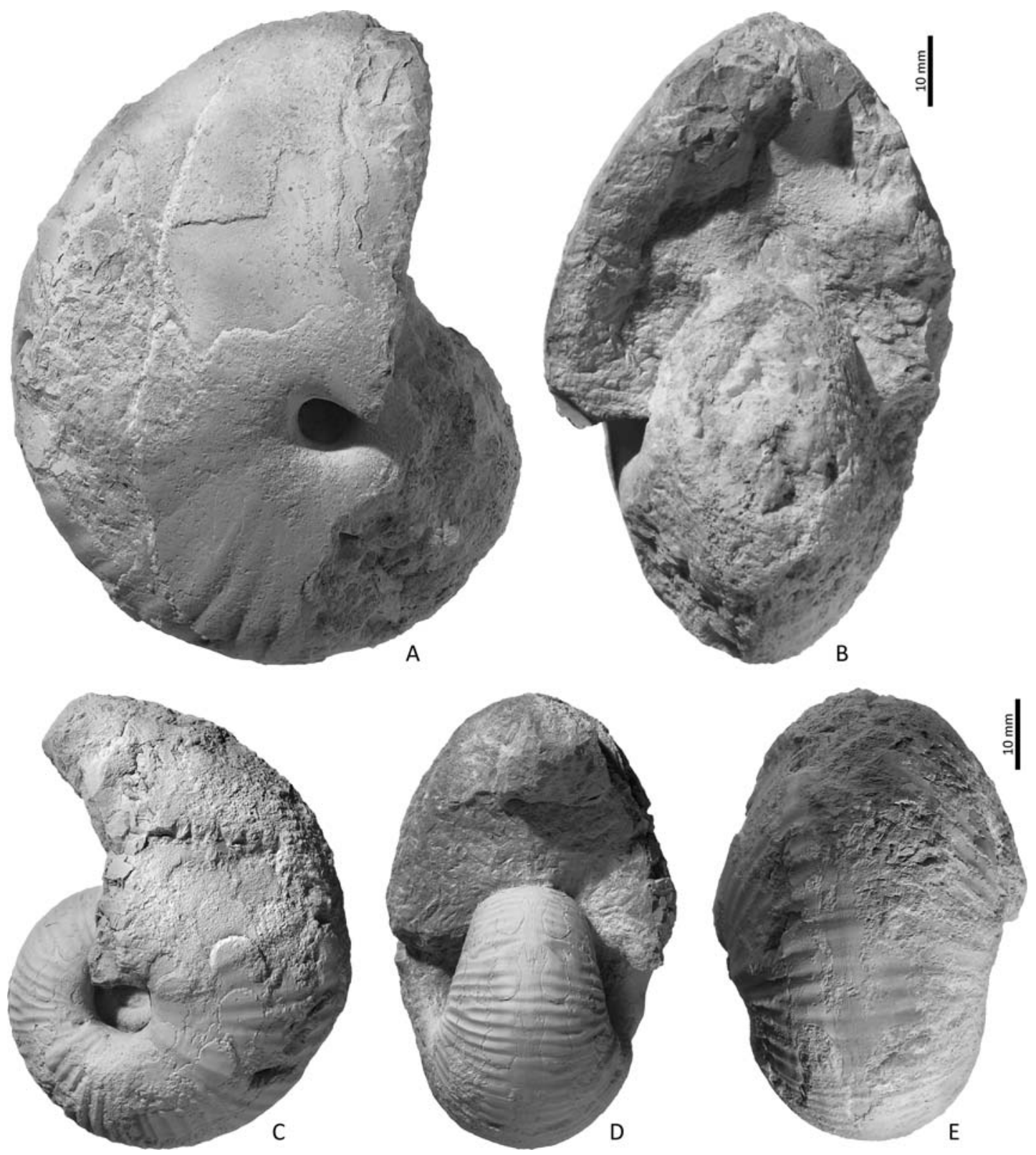

Figure 7. Globacrochordiceras transpacificum gen. et sp. nov. A-B. PIMUZ 29401, sample JIN 78, Jinya, Guangxi (South China); Neopopanoceras haugi Zone (upper Spathian, Early Triassic); C-E. PIMUZ 29402, sample JIN 78, Jinya, Guangxi (South China); holotype; Neopopanoceras haugi Zone (upper Spathian, Early Triassic).

Panthalassa (Fig. 1). A trans-Panthalassic distribution like that of Globacrochordiceras is striking, but in fact is frequent among Early and Middle Triassic ammonoids. For instance, Monnet et al. (2008) and Brayard et al. (2009a) described several ammonoid genera having such a peculiar palaeogeographical distribution. These taxa occurring on both east and west equatorial sides of Panthalassa suggest that ammonoid dispersal by oceanic currents was relatively frequent and that faunal exchange between both sides was intense during the Early and Middle Triassic. Furthermore, these genera generally have a short time-range and thus are crucial for highly detailed long-distance correlations. This intertropical distribution probably resulted from the interplay of several factors (see Brayard et al. 2009a) such as a juvenile planktonic phase of ammonoids (see De Baets et al. 2012), possible active long-distance migration of adults (see Brayard \& Escarguel 2013), thermal constraints on the life habitat of ammonoids, intense westward equatorial oceanic currents, and the presence of terranes as stepping stones within the intertropical belt (Brayard et al. 2009b). However, the exact contribution of each of these factors remains to be investigated.

Description. Shell coiling characterized by a regular increase of shell involution through ontogeny, from moderately involute inner whorls to involute mature whorls with a very narrow umbilicus. Whorl section changes from slightly depressed inner whorls to rela- 

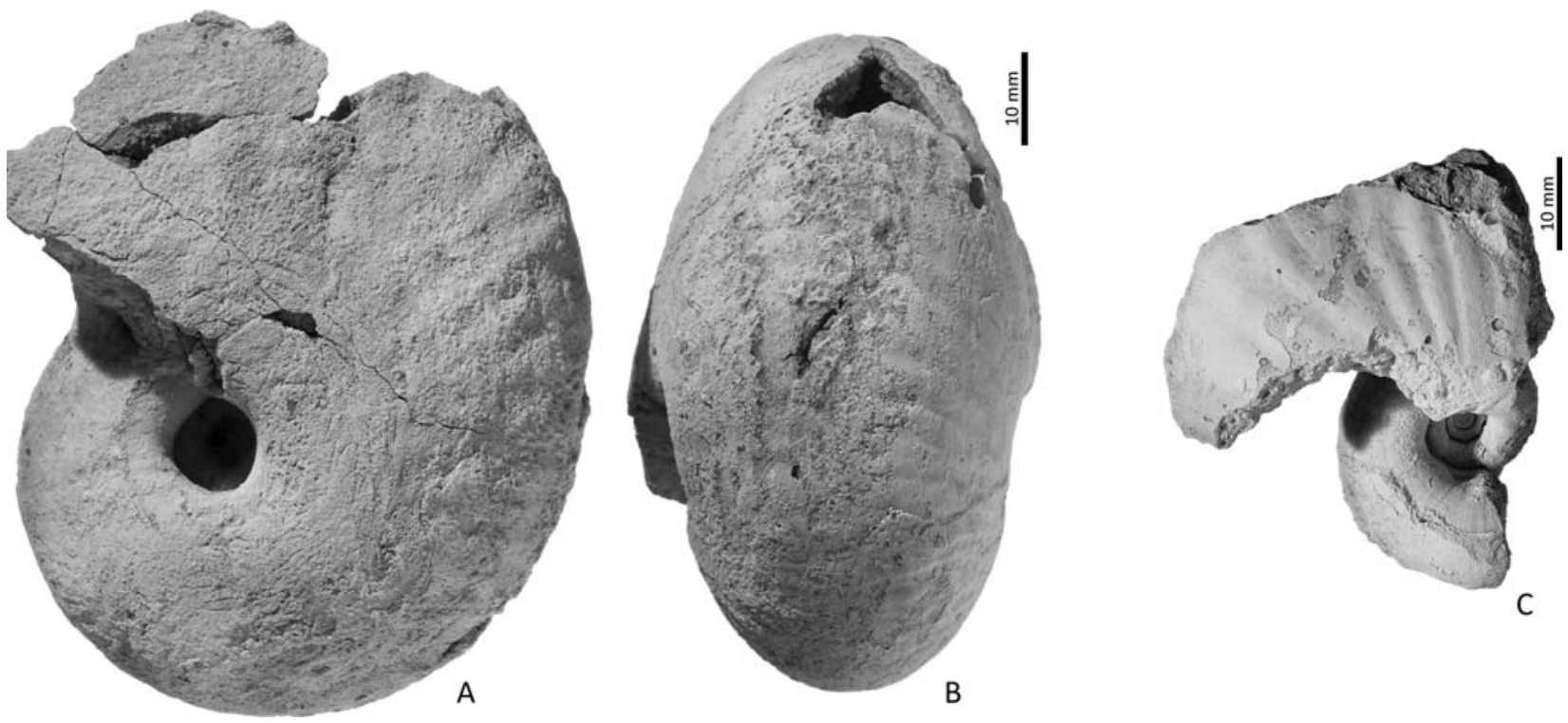

Figure 8. Globacrochordiceras transpacificum gen. et sp. nov. A-B. PIMUZ 29403, sample JIN 71, Jinya, Guangxi (South China), Neopopanoceras haugi Zone (upper Spathian, Early Triassic); C. PIMUZ 29404, sample JIN 71, Jinya, Guangxi (South China), Neopopanoceras haugi Zone (upper Spathian, Early Triassic).

tively compressed outer whorls; shell invariably highwhorled, high-oval with a large rounded venter, rounded indistinct ventral shoulders, rounded flanks with maximum whorl width near the umbilicus, narrow rounded umbilical shoulders, and deep overhanging umbilical wall. Ornamentation composed only by thin, numerous, straight to slightly sinuous, rectiradiate ribs that cross the venter without interruption and typically increase in strength from the umbilicus to the venter (the so-called plicate ribbing). Ribs usually single, but sometimes branching dichotomously at mid-flank. On the mature body chamber, ribs become sparser and decrease in strength near the venter without crossing the venter. Suture line subammonitic with weakly indented, rounded, narrow, elongated saddles, and deeply crenulated lobes with the first one being deeper and larger than the first saddle (Fig. 4).

\section{Discussion}

\section{Evolutionary history of Acrochordiceratidae during the Anisian}

Monnet et al. (2012) recently analysed in detail the long-term morphological evolution of Acrochordiceratidae during the Anisian. Their study analysed quantitatively and statistically the morphological changes of the acrochordiceratid shell, based on large collections (more than 700 specimens) from North America. This study showed that (1) the monophyletic clade of Acrochordiceratidae underwent a significant increase (possibly with several steps) of its adult shell diameter (i.e. Cope's rule), (2) the lineage also showed an evolute to involute evolutionary trend (i.e. an increase of shell involution), and (3) the clade furthermore experienced an increase of indentation of its suture line. Multiple ex-

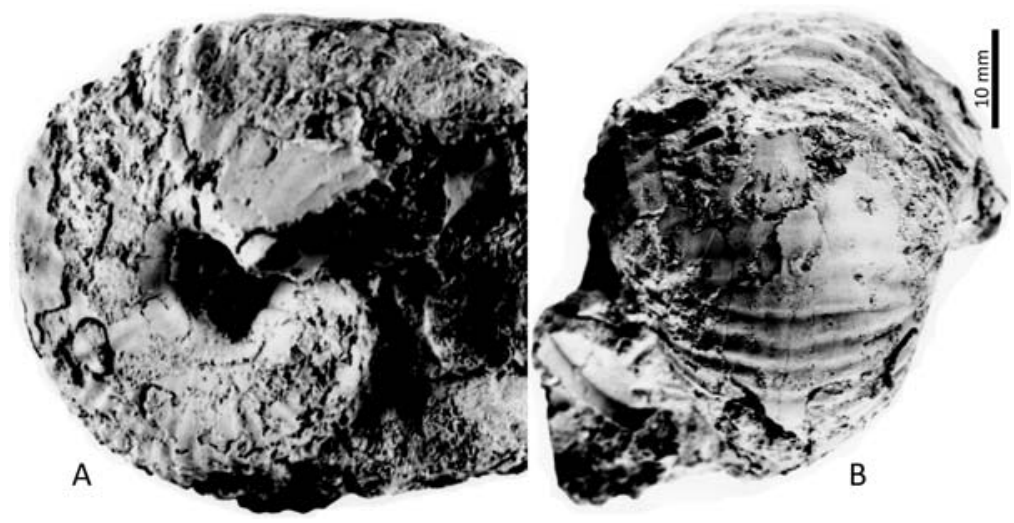

Figure 9. Globacrochordiceras transpacificum gen. et sp. nov. A-B. PIMUZ 24407, sample HB 110, Coyote Canyon (Humboldt Range), Nevada (USA); Neopopanoceras haugi Zone (upper Spathian, Early Triassic). 
amples of similar morphological trends in ammonoid shells have already been illustrated and discussed (e.g., Haas 1942; Guex 1973, 1992, 2006; Thierry 1982; Bayer \& McGhee 1984; Kennedy \& Wright 1985; Dommergues et al. 1989; Dommergues 1990; Klug et al. 2005; Monnet et al. 2011, 2012; De Baets et al. 2012).

The increasing body size of the studied lineage conforms with Cope's rule, known as the widespread tendency of animal groups to evolve toward larger body size (Newell 1949; Rensch 1960; Gould 1966). Size increase is commonly interpreted in terms of adaptive advantages such as increased defence against predation, increased food competition, increased success in mating, increased individual longevity and/or better energy use, among others (Stanley 1973; Brown \& Maurer 1986; Hone \& Benton 2005). For ammonoids, several authors illustrated and discussed examples of increasing ammonoid shell size (Stanley 1973; Hallam 1975; Thierry 1982; Guex 2003; Dommergues et al. 2002; Monnet et al. 2011, 2012; De Baets et al. 2012).

The increasing shell involution (i.e. protracted closure of the umbilicus by increasing overlap of the conch whorls) is also the most commonly described long-term morphological trends for ammonoids (see references above, as well as Hyatt 1889; Schindewolf 1940; Erben 1966; De Baets et al. 2009, 2012). Several studies interpreted such trends as the result of adaptive selection, which favoured more involute shell shapes for their improved hydrodynamics by drag reduction and increased manoeuvrability (Schmidt 1930; Raup 1967; Chamberlain 1976; Saunders \& Shapiro 1986; Elmi 1991, 1993; Jacobs 1992; Jacobs \& Chamberlain 1996; Klug \& Korn 2004).

The increasing suture indentation (frilling) is also a common pattern of ammonoid evolution, especially at large taxonomic ranks (Boyajian \& Lutz 1992; Saunders et al. 1999; Allen 2006). The classical morphofunctional interpretation (often called the Buckland hypothesis) is that increasing suture indentation leads to forms adapted to deeper water depth, because it is supposed to provide buttressing against hydrostatic pressure on the phragmocone (Buckland 1836; Pfaff 1911; Saunders 1995; De Blasio 2008; and references inside). However, this function of the septal folding remains controversial (Saunders 1995; Olóriz et al. 2002; Lewy 2002) and constructional constraints complicate its interpretation (see discussion in Monnet et al. 2011) leading to the idea that the evolution of the suture indentation of ammonoids exceeds their functional needs or limits.

The protracted changes in shell morphology of Acrochordiceratidae are robust and non-random (Monnet et al. 2012) and can be interpreted at first sight as being constrained by the persistent, common selection pressure on this mostly anagenetic lineage with relatively moderate evolutionary rates during an ecologically stable period. As discussed by Monnet et al. (2011), such trends in ammonoid shell (which acts as a buoyancy apparatus) could reflect that their morphology is mainly controlled by adaptive and constructional constraints.

\section{Evolutionary jump of Acrochordiceratidae at the Early/Middle Triassic boundary}

A persistent directed evolution toward larger adult shell diameter, more involute coiling and more indented suture line thus characterize the evolutionary history of Acrochordiceratidae during the Anisian (Monnet et al. 2012). The family is known to disappear at the middle/ late Anisian boundary (Monnet et al. 2008), but its earlier morphological and taxonomic history in the Spathian (Early Triassic) is poorly documented. Indeed, the oldest record of Acrochordiceratidae dates back to the late Spathian with the rare occurrence of Pseudacrochordiceras inyoense in the Neopopanoceras haugi Zone of California and Nevada (Smith 1914; Silberling \& Wallace 1969; Tozer 1994a; Guex et al. 2010; this study). With the discovery and herein description of the new genus Globacrochordiceras from Nevada and South China, the long-term morphological changes in Acrochordiceratidae can be more completely evaluated (Fig. 10).

On the one hand, the acrochordiceratids of the late Spathian (Globacrochordiceras and Pseudacrochordiceras) are large-sized (ca. $150 \mathrm{~mm}$ in shell diameter), high-whorled, involute to moderately evolute shells. These genera are restricted to the late Spathian and do not range across the Early/Middle Triassic boundary. On the other hand, the acrochordiceratids of the early Anisian (Paracrochordiceras) are small-sized (ca. $70 \mathrm{~mm}$ ), very evolute shells. Hence, early Anisian forms stand in sharp contrast with older late Spathian morphologies. Spathian acrochordiceratids were evidently not part of the long-term morphological trends documented in the Anisian (Fig. 10).

Strikingly, late Spathian forms closely resemble those of the late middle Anisian found at the end of the previously described evolutionary trends of the family. Therefore, the evolutionary history of Acrochordiceratidae is characterized by a marked and probably rapid (see below) change of shell morphology at the Spathian/Anisian (Early/Middle Triassic) boundary (Figs 10, 11). Then, this abrupt morphological change ("evolutionary jump", sensu Guex 1992) of Acrochordiceratidae is followed by a protracted shift (spanning ca. $4 \mathrm{Myr}$ ) of the shell morphology until the end of the middle Anisian (Figs 10,11). At the end of this latter morphological shift, the general morphology of Acrochordiceratidae is close, but not identical, to the original morphology of the group.

Due to common various possible biases of the fossil record, the documented morphological evolutionary jump may be at first regarded as spurious (see Raup \& Crick 1982). However, these biases are minimized thanks to a roughly equal amount of outcrops available 

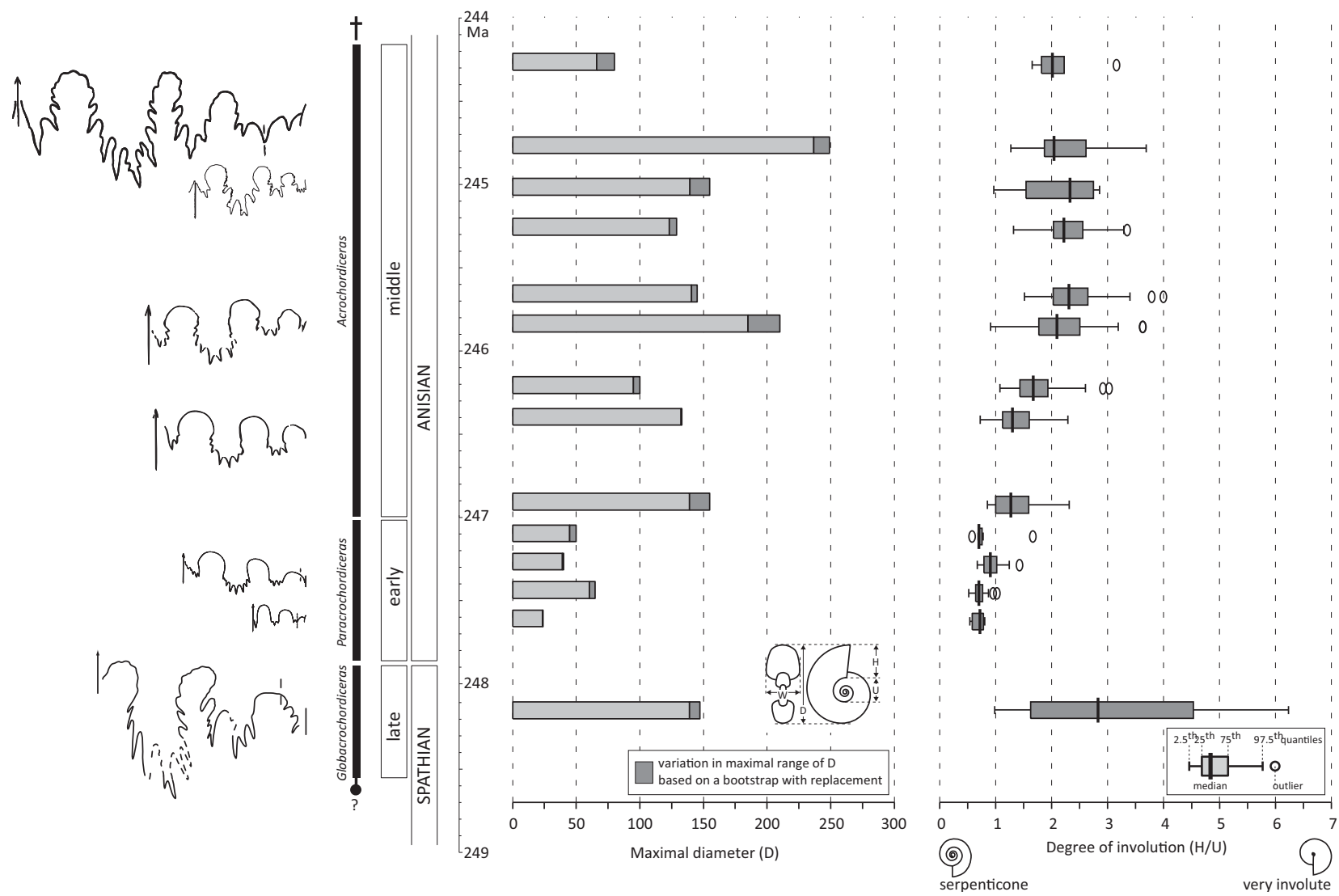

Figure 10. Evolution of suture shape, maximum shell diameter and degree of involution for Acrochordiceratidae during the late Spathian to the middle Anisian. Figure modified (after figs 4, 5, and 8 in Monnet et al. 2012) by adding Spathian data. See Monnet et al. (2012) for more details.

in the same basin for both the Spathian and the Anisian, a comparable sampling intensity throughout the studied interval, and similar relative abundances of preserved ammonoids. Furthermore, the possible influence of facies changes recorded at the Spathian/Anisian boundary (see below) is also reduced. Indeed, several authors discussed the possible relationships between ammonoid shell shape and facies (Jacobs et al. 1994; Olóriz et al. 1997; Kawabe 2003; Wilmsen \& Mosavinia 2011; further references in Monnet et al. 2011) but without a clear consensus. In the northern Humboldt Range, the depositional environment of strata of haugi Zone age does not significantly differ from that of the younger Anisian faunas (i.e. mixed siliclastic and carbonate outer platforms). In Guangxi, the depositional environment of strata of haugi Zone age also indicates an outer platform setting, but a very predominantly carbonate one. Hence, the presence of Globacrochordiceras is apparently independent from the amount of clastic input in those outer platform settings. Similarly, occurrences of Acrochordiceras range from the exclusively carbonate Hallstatt limestone in Europe to the mudstone of Guangxi. Therefore, the documented shape changes through time are not mirrored by any horizontal facies dependence, making these changes essentially of evolutionary significance and unrelated to facies variations. Furthermore, shell shapes resembling Paracro- chordiceras existed in the latest Spathian (e.g. Eodanubites; see Guex et al. 2010) and forms converging with Globacrochordiceras persisted in the early Anisian (e.g. Columbisculites, Isculites; see Bucher 1989; Tozer 1994b). Hence, the jump in morphology does not relate to the lack of certain facies around the Spathian/Anisian boundary since other taxa with similar shell shapes are present, if one accepts the underlying assumption that some link between facies and shell morphology can be established.

This morphological evolutionary jump of Acrochordiceratidae around the Early/Middle Triassic boundary is probably much faster than the protracted evolutionary trend of the family documented during the Anisian (estimated to last ca. $4 \mathrm{Myr}$ ). The available radio-isotopic ages for this time interval (see Ovtcharova et al. 2006 and Galfetti et al. 2007b) enable to estimate that this morphological jump lasted ca. 0.4 Myr.

The morphological evolutionary jump of Acrochordiceratidae documented around the Early/Middle Triassic boundary represents a peculiar pattern of evolution of ammonoids. Guex $(1992,2000,2001,2006)$ illustrated and discussed several such evolutionary jumps from a qualitative point of view. This author pointed out that these evolutionary jumps are characterized by the appearance of forms, which are partly homeomorphic with remote ancestors of their own lineage and inter- 


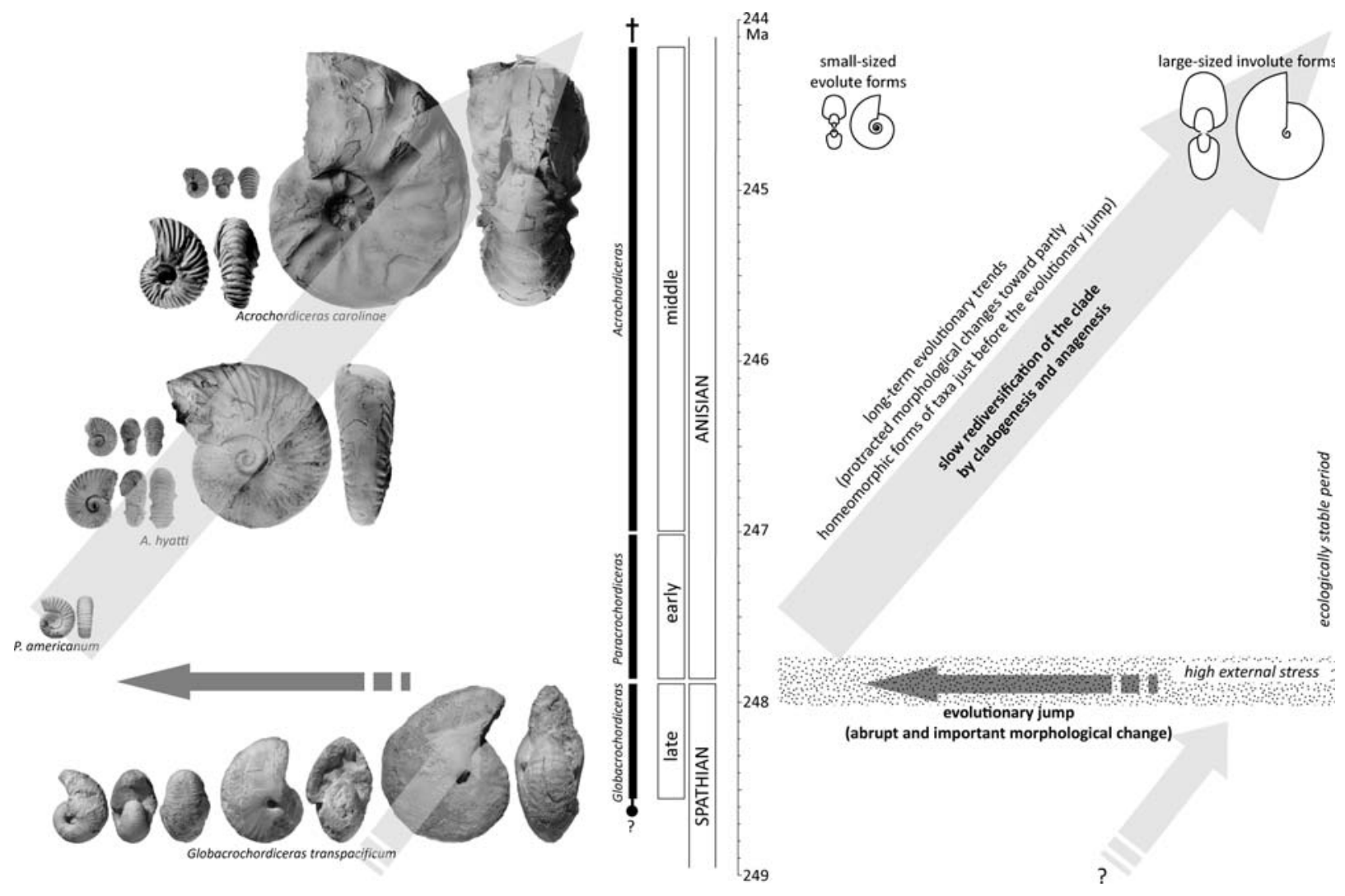

Figure 11. Sketch of the evolutionary history of shell morphology of Acrochordiceratidae. The lineage displays a sudden and drastic morphological change (evolutionary jump) at the Spathian/Anisian (Early/Middle Triassic) boundary probably triggered by a global regressive event and a global carbon isotope excursion. Then, the family displays a long-term morphological shift toward larger shells with more involute coiling and more indented suture line during a relatively ecologically stable period. The clade disappears at the middle/late Anisian boundary with forms close, but not identical, to the original Spathian ones. This kind of morphological evolutionary jump seems to be a frequent evolutionary pattern in ammonoids and at the origin of numerous ammonoid lineages. All figures are at the same scale.

preted these newly evolved homeomorphic taxa as being atavistic. In this context, the abrupt morphological evolutionary jump between Globacrochordiceras and Paracrochordiceras at the Spathian/Anisian (Early/ Middle Triassic) boundary may correspond to a generalized morphological reset of long-term trends (called proteromorphosis by Guex 2001), which cannot be explained by normal paedomorphic transformations (see Landman 1988).

\section{Stress-induced evolutionary jumps in ammonoids}

Guex $(1992,2001,2006)$ argued that episodes of strong environmental stress are at the origin of many new ammonoid lineages by promoting the abrupt appearance of significantly different forms by means of such evolutionary jumps. Indeed, stressful environments are well known to affect the normal development of organisms and to induce morphological variation and large phenotypic changes, as well as stronger phenotypic selection favouring different morphotypes (Parsons 1993; Hoffmann \& Parsons 1997; Bijlsma \& Loeschcke 1997; West-Eberhard 2003, 2005; Hallgrímsson \& Hall 2005; Badyaev 2005; Badyaev et al. 2005). For example,
Rutherford \& Lindquist (1998) demonstrated that mutant heat shock protein Hsp90 was responsible for a great variety of inheritable "abnormal" forms of drosophila. This suggests that an external stress (e.g., temperature) can uncover morphological variants for selection to act upon. Hence, in the fossil record, the abrupt appearance of morphologically distant organisms concomitant with intense environmental changes could result from such processes. Jablonski et al. (1983) argued also that many evolutionary novelties occurred in the more stressed nearshore environments. Among cephalopods, size reductions are well known to occur under stressful environments (Shimer 1908; Spath 1919; Kummel 1948; Mignot et al. 1993; Urlichs 2012), but there are exceptions. The phenomenon of miniaturization is widespread among many organisms and is frequently associated with evolutionary morphological novelties (Hanken \& Wake 1993), which are not related to simple paedomorphic transformations (Landman et al. 1991). Noteworthy, in highly stressed and widely fluctuating environments a punctuated evolutionary pattern is likely to happen (Parsons 1993). The morphological evolutionary jump of Acrochordiceratidae documented around the Early/Middle Triassic boundary may therefore represent such a case of evolution. Note- 
worthy, similar patterns of macroevolution have been described in other groups such as radiolarians (Guex et al. 2012) and foraminifers (Desmares et al. 2008).

For palaeontologists, the major evidence of extreme environmental changes is the occurrence of extinction periods. Noteworthy, the Early/Middle Triassic is associated with a drastic diversity (taxonomic richness) dropdown and a high turnover at the family level for ammonoids (see Brayard et al. 2009c). It coincides also with the first renewal of gymnosperm flora after the end-Permian mass extinction (Kürschner \& Herngreen 2010). Furthermore, in north-west Nevada, deposition of outer platform anoxic facies of the upper Spathian Tobin Formation was interrupted abruptly at the Early/ Middle Triassic boundary by deltaic deposits of the Dixie Valley Formation (see Nichols \& Silberling 1977; Bucher 1989). Open platform sedimentation resumed in the lower Anisian, with deposition of the Fossil Hill Member. Similarly, in South China, the Early/Middle Triassic boundary shows a drastic change in the mode of sedimentation from carbonate-dominated to siliciclastic-dominated depositional environments (Galfetti et al. 2008). These sedimentary events coincide with a second-order sequence boundary (transgressive-regressive cycle) recognized worldwide and mark a global and major sea-level change (Haq et al. 1987; Embry 1997; Gianolla \& Jacquin 1998; Egorov \& Mørk 2000; Hermann et al. 2011). The Early/Middle Triassic boundary also records a worldwide and pronounced positive excursion in carbon isotopes (Atudorei \& Baud 1997; Payne et al. 2004; Korte et al. 2005; Galfetti et al. 2007a, 2007b; Tanner 2010; Hermann et al. 2011). Hence, the Spathian/Anisian (Early/Middle Triassic) boundary is associated with significant global and stressful environmental changes, which affected the evolution of organism lineages. Acrochordiceratidae survived this event by generating a descendant (Paracrochordiceras) whose morphology stands in sharp contrast with older forms (Globacrochordiceras, Pseudacrochordiceras) (Figs 10,11). Further study will aim at identifying such evolutionary jumps in other ammonoid lineages around the Early/Middle Triassic boundary. The exact or most important stressors that may have played a role in the morphological evolutionary jump documented for Acrochordiceratidae remain to be identified. However, this awaits additional data and analyses especially on temperature and nutrient levels around the Spathian/Anisian boundary and on the phenotypic impact and inheritance of these factors on Recent cephalopods. Indeed, temperature, nutrient availability and ocean acidification among others are well known to impact shell ontogeny and morphology of extant molluses with accretionary growth (see Boletzky 2003; Przeslawski 2004; Boyle \& Rodhouse 2005; Pecl \& Jackson 2008; De Baets et al. 2012; Tamburi \& Martin 2012; Melatunan et al. 2013; Dorey et al. in press; Mattoo et al. in press; and references inside), although these changes are not systematic (see Schifano 1982; Gutowska et al. 2008) and not necessarily inheritable.

\section{Conclusions}

This study describes a new genus of Acrochordiceratidae (Ammonoidea, Cephalopoda), namely Globacrochordiceras, which records the oldest known member of the family. Globacrochordiceras is characterized by plicate ribbing (rounded ribs which strengthen when crossing the venter without interruption), increasing involution through ontogeny, overhanging and deep umbilical wall, absence of tuberculation, globular to subtriangular whorl section, and subammonitic adult suture line. This new taxon occurs in the Neopopanoceras haugi Zone (late Spathian, Early Triassic) of Nevada (USA) and Guangxi (South China).

This new genus highlights a peculiar pattern of ammonoid macroevolution, which is the evolutionary reaction of ammonoid lineages when exposed to heavy environmental stresses. On the one hand, the evolutionary history of the family consisted of long-term morphological trends (increases of adult size, degree of involution and indentation of the suture line) during the early and middle Anisian. On the other hand, the morphology of the Spathian Globacrochordiceras and Pseudacrochordiceras stands in sharp contrasts with the Anisian Paracrochordiceras and thus illustrates a case of an evolutionary jump of Acrochordiceratidae at the Early/ Middle Triassic boundary. This drastic morphological change coincided with stressful environments as reflected by a global second-order regression accompanied by a global carbon isotope excursion.

\section{Acknowledgements}

We greatly appreciated the help of Thomas Galfetti for fieldwork and ammonoid sampling. Rosemarie Roth and Markus Hebeisen provided technical support for photography and preparation. We acknowledge stimulating discussions with Jean Guex about this topic over the past years. We thank the two reviewers, Kenneth De Baets and Kevin Bylund, for their constructive comments and suggestions. The Swiss National Foundation supported this study (project $\mathrm{n}^{\circ} 135446$ ). AB is also supported by the Région Bourgogne and the CNRS INSU Interrvie.

\section{References}

Allen, E. G. 2006. New approaches to Fourier analysis of ammonoid sutures and other complex, open curves. - Paleobiology 32: 299-315.

Arkell, W. J., Furnish, W. M., Kummel, B., Miller, A. K., Moore, R. C., Schindewolf, O. H., Sylvester-Bradley, P. C. \& Wright, C. W. 1957. Cephalopoda, Ammonoidea. In Moore, R. C. (ed.). Treatise on invertebrate paleontology. Part L. Mollusca 4. - Geological Society of America, Boulder, CO, and University of Kansas Press, Lawrence, Kansas: pp. 1-490.

Arthaber, G. von 1911. Die Trias von Albanien. - Beiträge zur Paläontologie und Geologie des Österreich-Ungarns und des Orients 24: 169-277.

Atudorei, V. \& Baud, A. 1997. Carbon isotope events during the Triassic. - Albertiana 20: 45-49.

Badyaev, A. V. 2005. Stress-induced variation in evolution: from behavioural plasticity to genetic assimilation. - Proceedings of the Royal Society B 272: 877-886. 
Badyaev, A. V., Foresman, K. R. \& Young, R. L. 2005. Evolution of morphological integration: developmental accommodation of stress-induced variation. - The American Naturalist 166: 382395.

Bayer, U. \& McGhee, G. R. 1984. Iterative evolution of Middle Jurassic ammonite faunas. - Lethaia 17: 1-16.

Bijlsma, R. \& Loeschcke, V. 1997. Environmental stress, adaptation and evolution. Birkhäuser Verlag, Basel.

Blakey, R. 2011. Global paleogeography. http://cpgeosystems.com/globaltext2.html (2011).

Boletzky, S. V. 2003. Biology of early life stages in cephalopod molluscs. - Advances in Marine Biology 44: 143-203.

Boyajian, G. \& Lutz, T. 1992. Evolution of biological complexity and its relation to taxonomic longevity in the Ammonoidea. - Geology 20: $983-986$.

Boyle, P. \& Rodhouse, P. 2005. Cephalopods: Ecology and Fisheries. Oxford, Blackwell Science Ltd.

Brayard, A., Brühwiler, T., Bucher, H. \& Jenks, J. 2009a. Guodunites, a low-palaeolatitude and trans-Panthalassic Smithian (Early Triassic) ammonoid genus. - Palaeontology 52: 471-481.

Brayard, A. \& Escarguel, G. 2013. Untangling phylogenetic, geometric and ornamental imprints on Early Triassic ammonoid biogeography: a similarity-distance decay study. - Lethaia 46: 1933.

Brayard, A., Escarguel, G., Bucher, H. \& Brühwiler, T. $2009 \mathrm{~b}$. Smithian and Spathian (Early Triassic) ammonoid assemblages from terranes: paleoceanographic and paleogeographic implications. - Journal of Asian Earth Sciences 36: 420-433.

Brayard, A., Escarguel, G., Bucher, H., Monnet, C., Brühwiler, T., Goudemand, N., Galfetti, T. \& Guex, J. 2009c. Good genes and good luck: ammonoid diversity and the end-Permian mass extinction. - Science 325: 1118-1121.

Brown, J. H. \& Maurer, B. A. 1986. Body size, ecological dominance and Cope's rule. - Nature 324: 248-250.

Bucher, H. 1989. Lower Anisian ammonoids from the northern Humboldt Range (northwestern Nevada, USA) and their bearing upon the Lower-Middle Triassic boundary. - Eclogae geologicae Helvetiae 82: 945-1002.

Bucher, H. 1992. Ammonoids of the Hyatti Zone and the Anisian transgression in the Triassic Star Peak Group, Northwestern Nevada, USA. - Palaeontographica A223: 137-166.

Bucher, H. 2002. Early Anisian (Middle Triassic) ammonoid biostratigraphy of northeastern British Columbia. - Eclogae geologicae Helvetiae 95: 277-287.

Buckland, W. 1836. Geology and mineralogy considered with reference to natural theology. Pickering, London.

Chamberlain, J. A. 1976. Flow patterns and drag coefficients of cephalopod shells. - Palaeontology 19: 539-563.

Cuvier, G. 1797. Tableau élémentaire de l'histoire naturelle des animaux. Baudouin, Paris.

Dagys, A. \& Weitschat, W. 1993. Intraspecific variation in Boreal Triassic ammonoids. - Géobios 26: 107-109.

De Baets, K., Klug, C. \& Korn, D. 2009. Anetoceratinae (Ammonoidea, Early Devonian) from the Eifel and Harz Mountains (Germany), with a revision of their genera. - Neues Jahrbuch für Geologie und Palaontologie, Abhandlungen 252: 361-376.

De Baets, K., Klug, C., Korn, D. \& Landman, N. H. 2012. Early evolutionary trends in ammonoid embryonic development. - Evolution 66: 1788-1806.

De Baets, K., Klug, C. \& Monnet, C. 2013. Intraspecific variability through ontogeny in early ammonoids. - Paleobiology 39: 75-94.

De Blasio, F. V. 2008. The role of suture complexity in diminishing strain and stress in ammonoid phragmocones. - Lethaia 41: 1524.

Desmares, D., Grosheny, D. \& Beaudoin, B. 2008. Ontogeny and phylogeny of Upper Cenomanian rotaliporids (Foraminifera). - Marine Micropaleontology 69: 91-105.
Diener, C. 1895. Himalyan fossils. Vol. II. Part II. The Cephalopoda of the Muschelkalk. - Memoirs of the Geological Survey of India, Palaeontologia indica, Series 15, 2 (2): 1-120.

Diener, C. 1907. The fauna of the Himalayan Muschelkalk. - Memoirs of the Geological Survey of India, Palaeontologia indica, Series 15,5 (2): 1-140.

Diener, C. 1916. Einige Bemerkungen zur Nomenklatur der Triascephalopoden. - Centralblatt für Mineralogie, Geologie und Paläontologie 1916: 97-105

Dommergues, J. L. 1990. Chapter 7. Ammonoids. In McNamara, K. J. (ed.). Evolutionary trends. Belhaven Press, London: pp. 162-187.

Dommergues, J. L., Cariou, E., Contini, D., Hantzpergue, P., Marchand, D., Meister, C. \& Thierry, J. 1989. Homéomorphies et canalisations évolutives: le rôle de l'ontogenèse. Queslques exemples pris chez les ammonites du Jurassique. - Géobios 22: 5-48.

Dommergues, J. L., Montuire, S. \& Neige, P. 2002. Size patterns throught time: the case of the Early Jurassic ammonite radiation. - Paleobiology 28: 423-434.

Dorey, N., Melzner, F., Martin, S., Oberhänsli, F., Teyssié, J.-L., Bustamante, P., Gattuso, J.-P. \& Lacoue-Labarthe, T., in press. Ocean acidification and temperature rise: effects on calcification during early development of the cuttlefish Sepia officinalis. - Marine Biology, doi: 10.1007/s00227-012-2059-6

Egorov, A. Y. \& Mørk, A. 2000. The East Siberian and Svalbard Triassic successions and their sequence stratigraphical relationships. - Zentralblatt für Geologie und Paläontologie 1: 13771430 .

Elmi, S. 1991. Données expérimentales sur l'architecture fonctionnelle de la coquille des ammonoïdes Jurassiques. - Géobios, Mémoire Spécial 13: 155-160.

Elmi, S. 1993. Loi des aires, couche limite et morphologie fonctionnelle de la coquille des céphalopodes (ammonoïdes). - Géobios, Mémoire Spécial 15: 121-138.

Embry, A. F. 1997. Global sequence boundaries of the Triassic and their identification in the Western Canada Sedimentary Basin. Bulletin of Canadian Petroleum Geology 45: 415-433.

Erben, H. K. 1966. On the origin of Ammonoidea. - Über den Ursprung der Ammonoidea 41: 641-658.

Fantini Sestini, N. 1981. Lower Anisian (Aegean) ammonites from Chios Island (Greece). - Rivista Italiana di Paleontologia 87: 41-66.

Galfetti, T., Bucher, H., Brayard, A., Hochuli, P., Weissert, H., Guodun, K., Atudorei, V. \& Guex, J. 2007a. Late Early Triassic climate change: insights from carbonate carbon isotopes, sedimentary evolution and ammonoid paleobiogeography. - Palaeogeography Palaeoclimatology Palaeoecology 243: 394-411.

Galfetti, T., Bucher, H., Ovtcharova, M., Schaltegger, U., Brayard, A., Brühwiler, T., Goudemand, N., Weissert, H., Hochuli, P., Cordey, F. \& Guodun, K. 2007b. Timing of the Early Triassic carbon cycle perturbations inferred from new U-Pb ages and ammonoid biochronozones. - Earth and Planetary Science Letters 258: $593-$ 604.

Galfetti, T., Bucher, H., Martini, R., Hochuli, P. A., Weissert, H., Crasquin-Soleau, S., Brayard, A., Goudemand, N., Brühwiler, T. \& Guodun, K. 2008. Evolution of Early Triassic outer platform paleoenvironments in the Nanpanjiang Basin (South China) and their significance for the biotic recovery. - Sedimentary Geology 204: $36-60$

Gianolla, P. \& Jacquin, T. 1998. Triassic sequence stratigraphic framework of western European basins. In de Graciansky, P. C., Hardenbol, J., Jacquin, T., Vail, P. R. \& Ulmer-Scholle, D. (eds). Mesozoic-Cenozoic sequence stratigraphy of European basins. SEPM Special Publication (60). Society for Sedimentary Geology, Tulsa: pp. $643-650$

Gilder, S. A., Coe, R. S., Wu, H. R., Kunag, G. D., Zhao, X. X. \& Wu, Q. 1995. Triassic paleomagnetic data from South China and their bearing on the tectonic evolution of the western Circum-Pacific Region. - Earth and Planetary Science Letters 31: 269-287. 
Gould, S. J. 1966. Allometry and size in ontogeny and phylogeny. Biological Reviews 41: 587-640.

Guex, J. 1973. Observations sur la répartition biostratigraphique des ammonites du Toarcien supérieur de l'Aveyron (France). - Bulletin des Laboratoires de Géologie, Minéralogie, Géophysique et du Musée géologique de l'Université de Lausanne 207: 1-14.

Guex, J. 1992. Origine des sauts évolutifs chez les ammonites. - Bulletin de la Société Vaudoise de Sciences Naturelles 82: 117-144.

Guex, J. 2000. Paronychoceras gen. n., un nouveau genre d'ammonites (Cephalopoda) du Lias supérieur. - Bulletin de la Société Vaudoise de Sciences Naturelles 87: 115-124.

Guex, J. 2001. Environmental stress and atavism in ammonoid evolution. - Eclogae geologicae Helvetiae 94: 321-328.

Guex, J. 2003. A generalization of Cope's rule. - Bulletin de la Société géologique de France 174: 449-452.

Guex, J. 2006. Reinitialization of evolutionary clocks during sublethal environmental stress in some invertebrates. - Earth and Planetary Science Letters 242: 240-253.

Guex, J., Hungerbühler, A., Jenks, J., Taylor, D. \& Bucher, H. 2005 a. Dix-huit nouveaux genres d'ammonites du Spathien (Trias inférieur) de 1'Ouest américain (Idaho, Nevada, Utah et Californie): note préliminaire. - Bulletin de Géologie de Lausanne 362: 131 .

Guex, J., Hungerbühler, A., Jenks, J., Taylor, D. \& Bucher, H. 2005b. Dix-neuf nouvelles espèces d'ammonites du Spathien (Trias inférieur) de l'Ouest américain (Idaho, Nevada, Utah et Californie): note préliminaire. - Bulletin de Géologie de Lausanne 363: 125 .

Guex, J., Hungerbühler, A., Jenks, J. F., O’Dogherty, L., Atudorei, V., Taylor, D. G., Bucher, H. \& Bartolini, A. 2010. Spathian (Lower Triassic) ammonoids from western USA (Idaho, California, Utah and Nevada). - Mémoires de Géologie Lausanne 49: 1-203.

Guex, J., O’Dogherty, L., Carter, E.S., Goričan, Š., Dumitrica, P. \& Bartolini, A. 2012. Geometrical transformations of selected Mesozoic radiolarians. - Geobios 45: 541-554

Gutowska, M. A., Pörtner, H. O. \& Melzner, F. 2008. Growth and calcification in the cephalopod Sepia officinalis under elevated seawater pCO2. - Marine Ecology Progress Series 373: 303-309.

Haas, O. 1942. Recurrence of morphologic types and evolutionary cycles in Mesozoic ammonites. - Journal of Paleontology 16: 643650 .

Hallam, A. 1975. Evolutionary size increase and longevity in Jurassic bivalves and ammonites. - Nature 258: 493-496.

Hallgrímsson, B. \& Hall, B. K. 2005. Variation: a central concept in biology. Elsevier Academic Press, Amsterdam.

Hammer, Ø. \& Bucher, H. 2005. Buckman's first law of covariation a case of proportionality. - Lethaia 38: 67-72.

Hanken, J. \& Wake, D. B. 1993. Miniaturization of body size: organismal consequences and evolutionary significance. - Annual Review of Ecology and Systematics 24: 501-519.

Haq, B. U., Hardenbol, J. \& Vail, P. R. 1987. Chronology of fluctuating sea levels since the Triassic. - Science 235: 1156-1167.

Hermann, E., Hochuli, P. A., Méhay, S., Bucher, H., Brühwiler, T., Ware, D., Hautmann, M., Roohi, G., Ur-Rehman, K. \& Yaseen, A 2011. Organic matter and palaeoenvironmental signals during the Early Triassic biotic recovery: the Salt Range and Surghar Range records. - Sedimentary Geology 234: 19-41.

Hoffmann, A. A. \& Parsons, P. A. 1997. Extreme environmental change and evolution. Cambridge University Press, Cambridge.

Hone, D. W. E. \& Benton, M. J. 2005. The evolution of large-size: how does Cope's rule work? - Trends in Ecology and Evolution 20: $4-6$

Hyatt, A. 1877. in Meek 1877.

Hyatt, A. 1884. Genera of fossil cephalopods. - Proceedings of the Boston Society of Natural History 22: 273-338.

Hyatt, A. 1889. Genesis of the Arietitidae. - Smithsonian Contributions to Knowledge 673: 1-238.
Jablonski, D., Sepkoski, J. J., Bottjer, D. J. \& Sheehan, P. M. 1983 Onshore-offshore patterns in the evolution of Phanerozoic shelf communities. - Science 22: 1123-1125.

Jacobs, D. K., 1992. Shape, drag, and power in ammonoid swimming. - Paleobiology 18: 203-220.

Jacobs, D. K. \& Chamberlain, J. A. 1996. Buoyancy and hydrodynamics in ammonoids. In Landman, N. H., Tanabe, K. \& Davis, R. A. (eds). Ammonoid paleobiology. Topics in Geobiology 13 Plenum Press, New York: pp. 169-223.

Jacobs, D. K., Landman, N. H. \& Chamberlain, J. A. 1994. Ammonite shell shape covaries with facies and hydrodynamics: iterative evolution as a response to changes in basinal environment. - Geology 22: 905-908.

Kawabe, F. 2003. Relationship between mid-Cretaceous (upper AlbianCenomanian) ammonoid facies and lithofacies in the Yezo forearc basin, Hokkaido, Japan. - Cretaceous Research 24: 751-763.

Kennedy, W. J. \& Cobban, W. A. 1976. Aspects of ammonite biology, biogeography, and biostratigraphy. - Special Papers in Palaeontology 17: 1-94.

Kennedy, W. J. \& Wright, C. W. 1985. Evolutionary patterns in Late Cretaceous ammonites. - Special Papers in Palaeontology 33: $131-143$.

Klug, C. \& Korn, D. 2004. The origin of ammonoid locomotion. Acta Palaeontologica Polonica 49: 235-242.

Klug, C., Schatz, W., Korn, D. \& Reisdorf, A. G. 2005. Morphological fluctuations of ammonoid assemblages from the Muschelkalk (Middle Triassic) of the Germanic Basin - indicators of their ecology, extinctions, and immigrations. - Palaeogeography $\mathrm{Pa}$ laeoclimatology Palaeoecology 221: 7-34.

Korn, D. 2010. A key for the description of Palaeozoic ammonoids. Fossil Record 13: 5-12.

Korschinskaya, V. M. 1983. New ceratitids from the Upper Olenek sediments of Spitsbergen. - Paleontological Journal 17: 109-112. [In Russian].

Korte, C., Kozur, H. W. \& Veizer, J. 2005. $\delta^{13} \mathrm{C}$ and $\delta^{18} \mathrm{O}$ values of Triassic brachiopods and carbonate rocks as procies for coeval saewater and palaeotemperature. - Palaeogeography Palaeoclimatology Palaeoecology 226: 287-306.

Kummel, B. 1948. Environmental significance of dwarfed cephalopods. - Journal of Sedimentary Research 18: 61-64.

Kürschner, W. M. \& Herngreen, G. F. W. 2010. Triassic palynology of central and northwestern Europe: a review of palynofloral diversity patterns and biostratigraphic subdivisions. In Lucas, S. G. (ed.). The Triassic Timescale. - Geological Society London Special Publications 334: 263-283.

Landman, N. H. 1988. Heterochrony in ammonites. In McKinney, M. L. (ed.). Heterochrony in Evolution. Plenum Press, New York: pp. $159-182$.

Landman, N. H., Dommergues, J. L. \& Marchand, D. 1991. The complex nature of progenetic species - examples from Mesozoic ammonites. - Lethaia 24: 409-421.

Lehrmann, D. J., Wei, J. Y. \& Enos, P. 1998. Controls on facies architecture of a large Triassic carbonate platform: the Great Bank of Guizhou, Nanpanjiang Basin, South China. - Journal of Sedimentary Research 68: 311-326.

Lehrmann, D. J., Enos, P., Payne, J. L., Montgomery, P., Wei, J. Y., Yu, Y., Xiao, J. \& Orchard, M. J. 2005. Permian and Triassic depositional history of the Yangtze platform and Great Bank of Guizhou in the Nanpanjiang basin of Guizhou and Guangxi, south China. - Albertiana 33: 149-168.

Lewy, Z. 2002. The function of the ammonite fluted septal margins. Journal of Paleontology 76: 63-69.

Linnaeus, C. 1758. Systema Naturae. - Holmiae, $10^{\text {th }}$ edition.

Martelli, A. 1906. Contributo al Muschelkalk superiore del Montenegro. - Paleotongraphica Italiana 23: 323-361.

Mattoo, O. B., Ivanina, A. V., Ullstad, C., Beniash, E. \& Sokolova, I. M., in press. Interactive effects of elevated temperature and 
$\mathrm{CO}_{2}$ levels on metabolism and oxidative stress in two common marine bivalves (Crassostrea virginica and Mercenaria mercenaria). - Comparative Biochemistry and Physiology, Part A, doi: 10.1016/j.cbpa.2012.12.025

McLearn, F. H. 1946. A Middle Triassic (Anisian) fauna in Halfway, Sikanni Chief, and Tetsa Valleys, northeastern British Columbia. - Geological Survey of Canada 46: 1-23.

McLearn, F. H. 1969. Middle Triassic (Anisian) ammonoids from northeastern British Columbia and Ellesmere Island. - Bulletin of the Geological Survey of Canada 170: 1-90.

Meek, F. B. 1877. Paleontology. - U.S. Geological Exploration of the Fourtieth Parallel, Report 4: 99-129.

Melatunan, S., Calosi, P., Rundle, S. D., Widdicombe, S. \& Moody, A. J. 2013. Effects of ocean acidification and elevated temperature on shell plasticity and its energetic basis in an intertidal gastropod. - Marine Ecology Progress Series 472: 155-168.

Mignot, Y., Elmi, S. \& Dommergues, J. L. 1993. Croissance et miniaturisation de quelques Hildoceras (Cephalopoda) en liaison avec des environnements contraignant de la Téthys toarcienne. - Géobios, Mémoire Special 15: 305-312.

Mojsisovics, E. von 1879. Vorläufige kurze Übersicht der Ammoniten-Gattungen der mediterranen und juvavischen Trias. - Verhandlungen der geologischen Reichsanstalt Wien: 133-143.

Mojsisovics, E. von 1882. Die Cephalopoden der mediterranen Triasprovinz. - Abhandlungen der kaiserlich-königlichen geologischen Reichanstalt 10: 1-322.

Monnet, C. \& Bucher, H. 2005a. New Middle and Late Anisian (Middle Triassic) ammonoid faunas from northwestern Nevada (USA): taxonomy and biochronology. - Fossils and Strata 52: 1-121.

Monnet, C. \& Bucher, H. 2005b (2006). Anisian (Middle Triassic) ammonoids from North America: quantitative biochronology and biodiversity. - Stratigraphy 2: 311-326.

Monnet, C., Brack, P., Bucher, H. \& Rieber, H. 2008. Ammonoids of the middle/late Anisian boundary (Middle Triassic) and the transgression of the Prezzo Limestone in eastern Lombardy-Giudicarie (Italy). - Swiss Journal of Geosciences 101: 61-84.

Monnet, C., Bucher, H., Wasmer, M. \& Guex, J. 2010. Revision of the genus Acrochordiceras Hyatt, 1877 (Ammonoidea, Middle Triassic): morphology, biometry, biostratigraphy and intraspecific variability. - Palaeontology 53: 961-996.

Monnet, C., Bucher, H., Guex, J. \& Wasmer, M. 2012. Large-scale evolutionary trends of Acrochordiceratidae Arthaber, 1911 (Ammonoidea, Middle Triassic) and Cope's rule. - Palaeontology 55: 87-107.

Monnet, C., De Baets, K. \& Klug, C. 2011. Parallel evolution controlled by adaptation and covariation in ammonoid cephalopods. BMC Evolutionary Biology 11:115: 1-21, doi:10.1186/14712148-11-115.

Newell, N. D. 1949. Phyletic size increase, an important trend illustrated by fossil invertebrates. - Evolution 3: 103-124.

Nichols, K. M. \& Silberling, N. J. 1977. Stratigraphy and depositional history of the Star Peak Group (Triassic), northwestern Nevada. Geological Society of America Special Paper 178: 1-73.

Noetling, F. 1880. Die Entwickelung der Trias in Niederschlesien. Zeitschrift der Deutschen geologischen Gesellschaft 32: 300349.

Olóriz, F., Palmqvist, P. \& Pérez-Claros, J. A. 1997. Shell features, main colonized environments, and fractal analysis of sutures in Late Jurassic ammonites. - Lethaia 30: 191-204.

Olóriz, F., Palmqvist, P. \& Pérez-Claros, J. A. 2002. Morphostructural constraints and phylogenetic overprint on sutural frilling in Late Jurassic ammonites. - Lethaia 35: 158-168.

Ovtcharova, M., Bucher, H., Schaltegger, U., Galfetti, T., Brayard, A. \& Guex, J. 2006. New Early to Middle Triassic U-Pb ages from South China: calibration with ammonoid biochronozones and implications for the timing of the Triassic biotic recovery. - Earth and Planetary Science Letters 243: 463-475.
Parsons, P. A. 1993. The importance and consequences of stress in living and fossil populations: from life-history variation to evolutionary change. - The American Naturalist 142: S5-S20.

Payne, J. L., Lehrmann, D. J., Wei, J., Orchard, M. J., Schrag, D. P. \& Knoll, A. H. 2004. Large perturbations of the carbon cycle during recovery from the end-Permian extinction. - Science 305: 506509

Pecl, G. T. \& Jackson, G. D. 2008. The potential impacts of climate change on inshore squid: biology, ecology and fisheries. - Reviews in Fish Biology and Fisheries 18: 373-385.

Pfaff, E. 1911. Über Form und Bau der Ammonitensepten und ihre Beziehungen zur Suturlinie. - Jahreshefte des Niedersächischen Geologischen Vereins Hannover 4: 207-223.

Przeslawski, R. 2004. A review of the effects of environmental stress on embryonic development within intertidal gastropod egg masses. - Molluscan Research 24: 43-63.

Raup, D. M. 1967. Geometric analysis of shell coiling: coiling in ammonoids. - Journal of Paleontology 41: 43-65.

Raup, D. M. \& Crick, R. E. 1982. Kosmoceras: evolutionary jumps and sedimentary breaks. - Paleobiology 8: 90-100.

Rensch, B. 1960. Evolution above the species level. Columbia University Press, New York.

Rutherford, S. L. \& Lindquist, S. 1998. Hsp90 as a capacitor for morphological evolution. - Nature 396: 336-342.

Saunders, W. B. 1995. The ammonoid suture problem: relationships between shell and septum thickness and suture complexity in $\mathrm{Pa}$ leozoic ammonoids. - Paleobiology 21: 343-355.

Saunders, W. B. \& Shapiro, E. A. 1986. Calculation and simulation of ammonoid hydrostatics. - Paleobiology 12: 64-79.

Saunders, W. B., Work, D. M. \& Nikolaeva, S. V. 1999. Evolution of complexity in Paleozoic ammonoid sutures. - Science 286: 760763

Schifano, G. 1982. Temperature effects on shell mineralogy and morphology in three gastropod species. - Marine Geology 45: 79-91.

Schindewolf, O. H. 1940. Konvergenz bei Korallen und bei Ammoniten. - Fortschritte der Geologie und Paläontologie 12: 387-491.

Schmidt, H. 1930. Uber die Bewegungsweise der Schalencephalopoden. - Paläontologische Zeitschrift 12: 194-208.

Shevyrev, A. A. 1968. Triassic ammonoids of south USSR. - Trudy Paleontologiceskogo Instituta 119: 1-251. [In Russian].

Shevyrev, A. A. 1995. Triassic ammonites of northwestern Caucasus. - Moscow, Nauka. [In Russian].

Shimer, H. W. 1908. Dwarf faunas. - The American Naturalist 42: $472-490$.

Silberling, N. J. \& Nichols, K. M. 1982. Middle Triassic molluscan fossils of biostratigraphic significance from the Humboldt Range, north-western Nevada. - U.S. Geological Survey Professional Paper 1207: 1-77.

Silberling, N. J. \& Tozer, E. T. 1968. Biostratigraphic classification of the marine Triassic in North America. - Geological Society of America Special Paper 110: 1-63.

Silberling, N. J. \& Wallace, R. E. 1969. Stratigraphy of the Star Peak Group (Triassic) and overlying Lower Mesozoic rocks, Humboldt Range, Nevada. - U.S. Geological Survey Professional Paper 592: $1-50$.

Smith, J. P. 1914. The Middle Triassic marine invertebrate faunas of North America. - U.S. Geological Survey Professional Paper 83 $1-254$.

Spath, L. F. 1919. Notes on ammonites. - Geological Magazine 6: 27-35.

Spath, L. F. 1934. Catalogue of the fossil Cephalopoda in the British Museum (Natural History), Part IV, The Ammonoidea of the Trias. British Museum (Natural History), London.

Stanley, S. M. 1973. An explanation for Cope's rule. - Evolution 27: $1-26$

Tamburi, N. E. \& Martín, P. R. 2012. Effect of food availability on morphometric and somatic indices of the apple snail Pomacea ca- 
naliculata (Caenogastropoda, Ampullariidae). - Malacologia 55: 33-41.

Tanner, L. H. 2010. The Triassic isotope record. In Lucas, S. G. (ed.) The Triassic Timescale. - Geological Society, London, Special Publications 334: 103-118.

Thierry, J. 1982. Rythme d'évolution des caractères morphologiques chez les Macrocephalitidae (Cephalopoda, Ammonitina, Jurassique moyen). In Chaline, J. (ed.). Modalités, rythmes, mécanismes de 1'évolution biologique. - Colloques Internationaux du Centre National de la Recherche Scientifique 330: 211-218.

Tozer, E. T. 1981. Triassic Ammonoidea: classification, evolution and relationship with Permian and Jurassic forms. In House, M. R. \& Senior, J. R. (eds). The Ammonoidea: the evolution, classification, mode of life and geological usefulness of a major fossil group. The Systematics Association, Special Volume 18: 65-100.

Tozer, E. T. 1994a. Significance of Triassic stage boundaries defined in North America. - Mémoires de Géologie Lausanne 22: 155-170.

Tozer, E. T. 1994b. Canadian Triassic ammonoid faunas. - Geological Survey of Canada Bulletin 467: 1-663.

Urlichs, M. 2012. Stunting in some invertebrates from the Cassian Formation (Late Triassic, Carnian) of the Dolomites (Italy). Neues Jahrbuch für Geologie und Palaontologie, Abhandlungen 265: $1-25$.

Wang, Y. 1978. Latest Early Triassic ammonoids of Ziyun, Guizhou - with notes on the relationship between Early and Middle Triassic ammonoids. - Acta Palaeontologica Sinica 17: 151-177. [In Chinese, English summary].

Waterhouse, J. B. 1999. The early and middle Triassic ammonoid succession of the Himalayas in western and central Nepal. - Palaeontographica, Abteilung A 255: 1-84.
Waterhouse, J. B. 2002. The early and middle Triassic ammonoid succession of the Himalayas in western and central Nepal. - Palaeontographica, Abteilung A 266: 121-198.

Weitschat, W. \& Dagys, A. S. 1989. Triassic biostratigraphy of Svalbard and a comparison with NE-Siberia. - Mitteilungen aus dem Geologisch-Paläontologischen Institut der Universität Hamburg 68: 179-213.

Welter, O. 1915. Die Ammoniten und Nautiliden der Ladinischen und Anisischen Trias von Timor. - Paläontologie von Timor 5: 71136.

West-Eberhard, M. J. 2003. Developmental plasticity and evolution. Oxford University Press, Oxford.

West-Eberhard, M. J. 2005. Developmental plasticity and the origin of species differences. - Proceedings of the National Academy of Sciences 102: 6543-6549.

Westermann, G. E. G. 1966. Covariation and taxonomy of the Jurassic ammonite Sonninia adicra (Waagen). - Neues Jahrbuch für Geologie und Paläontologie Abhandlungen 124: 289-312.

Wilmsen, M. \& Mosavinia, A. 2011. Phenotypic plasticity and taxonomy of Schloenbachia varians (J. Sowerby, 1817) (Cretaceous Ammonoidea). - Palaontologische Zeitschrift 85: 169-184.

Yacobucci, M. M. 2004. Buckman's Paradox: variability and constraints on ammonoid ornament and shell shape. - Lethaia 37: $57-69$.

Zharnikova, N. K. 1981. New Anisian ceratites of the family Acrochordiceratidae from southern Primorye. - Paleontological Journal, Moscow 1: 29-37. [In Russian].

Zittel, K. A. von 1884. Paläozoologie II. Handbuch der Paläontologie 1. Oldenburg, München. 